OPEN ACCESS

Edited by:

Mirjana Rajilić-Stojanović,

University of Belgrade, Serbia

Reviewed by:

Ken $\mathrm{Ng}$,

The University of Melbourne, Australia

Irena Krga,

University of Belgrade, Serbia

*Correspondence:

He Huang

huang@tju.edu.cn

Specialty section:

This article was submitted to

Nutrition and Microbes,

a section of the journal

Frontiers in Nutrition

Received: 19 October 2021 Accepted: 25 November 2021

Published: 14 December 2021

Citation:

Wang L, Gao M, Kang G and Huang H (2021) The Potential Role of

Phytonutrients Flavonoids Influencing

Gut Microbiota in the Prophylaxis and

Treatment of Inflammatory Bowel

Disease. Front. Nutr. 8:798038

doi: 10.3389/fnut.2021.798038

\section{The Potential Role of Phytonutrients Flavonoids Influencing Gut Microbiota in the Prophylaxis and Treatment of Inflammatory Bowel Disease}

\author{
Lina Wang ${ }^{1,2}$, Mengxue Gao ${ }^{1,2}$, Guangbo Kang ${ }^{1,2}$ and He Huang ${ }^{1,2 *}$ \\ ${ }^{1}$ Department of Biochemical Engineering, School of Chemical Engineering and Technology, Tianjin University, Tianjin, China, \\ ${ }^{2}$ Frontiers Science Center for Synthetic Biology and Key Laboratory of Systems Bioengineering, Ministry of Education, Tianjin \\ University, Tianjin, China
}

Inflammatory bowel disease (IBD), characterized by the chronic inflammation of the gastrointestinal tract, is comprised of two idiopathic chronic intestinal inflammatory diseases. As the incidence of IBD increases, so does the need for safe and effective treatments. Trillions of microorganisms are colonized in the mammalian intestine, coevolve with the host in a symbiotic relationship. Gut microbiota has been reported to be involved in the pathophysiology of IBD. In this regard, phytonutrients flavonoids have received increasing attention for their anti-oxidant and anti-inflammatory activities. In this review, we address recent advances in the interactions among flavonoids, gut microbiota, and IBD. Moreover, their possible potential mechanisms of action in IBD have been discussed. We conclude that there is a complex interaction between flavonoids and gut microbiota. It is expected that flavonoids can change or reshape the gut microbiota to provide important considerations for developing treatments for IBD.

Keywords: phytonutrients, flavonoids, gut microbiota, IBD, gut homeostasis

\section{INTRODUCTION}

In recent years, some studies have investigated complex and chronic diseases, including Inflammatory bowel disease (IBD), and focused on their association with the gut microbiota in the intestines. The incidence of IBD has persistently increased with over 3.5 million affected people and has become a global epidemic disease threatening human health $(1,2)$. Two major defined forms of IBD include ulcerative colitis (UC) and Crohn's disease (CD), characterized by chronic progressive inflammation, which affects the whole gastrointestinal tract and colon mucosa, respectively, leading to an increased risk of colon cancer. There has been substantial research undertaken on the cause of IBD, such as genetic interaction between the human gut microbiome and mucosal immune system, as well as changes in environmental factors (3). There is an intricate interrelationship between the IBD and gut microbiota. It has been reported that gut microbes consist of about 100 trillion microorganisms. The ratio of the number of gut microbes to human cells is close to 1:1, covering more than 1,100 species known to the human body, and the genes displayed are 100 times that of the human genome (4-6). This implies that the gut microbiota is a key component in the human body, playing important roles in the regulation of intestinal permeability, education of 
host immune responses, metabolism of dietary nutrients, and host's protection against invading pathogens $(7,8)$. With the increase in the availability of multi-omics approaches, the gradually-revealed mechanism of interaction between gut microbiota and the host has been thought to be distinct in healthy individuals than the IBD patients. The development of various large-scale microbiome projects, such as metagenomics of human intestinal tract (MetaHIT) (5), human microbiome project (HMP), and integrative human microbiome project (iHMP) $(9,10)$ reveals that the composition, diversity, and stability of gut microbiota are associated with the normal physiological functions and occurrence of diseases (11). The disorders in intestinal microbiota result in perturbation in the intestinal homeostasis and eventually contribute to the IBD.

Diet is a major contributor in shaping the composition and function of human intestinal microbiota by directly or indirectly affects. The complex interactions between diet and intestinal microbiota determines the beneficial or harmful effects on human health, which may be due to the immunomodulatory effects of the improved microbiota, downstream effects on host gene expression, or changes in the metabolite landscape produced by the microbiota (12). The increasing numbers of epidemiological studies have pointed toward the beneficial effects of phytonutrients to decrease the incidence of chronic diseases, including cardiovascular diseases, neurodegenerative diseases, and cancer $(13,14)$. Flavonoids are present as secondary metabolites in various fruits and vegetables in their different parts, representing a large representative family of the phytonutrients compounds with anti-oxidants and antimicrobial properties. Flavonoids are supplied as nutrition and food additives in functional dietary supplements because of their beneficial effects on human health $(15,16)$. Some studies have simultaneously demonstrated the beneficial effects of flavonoids on host energy metabolism by regulating the intestinal microbiota and suggested that the diversity and abundance of the intestinal microbiota are associated with the consumption of flavonoids (17-19). At present, flavonoids are considered to be vital for the treatment of acute or chronic intestinal inflammation through multiple mechanisms, including resistance to oxidative stress, protection of intestinal epithelial barrier, and immunomodulation (20). In this review, we summarized the classification and structural characteristics of phytonutrient flavonoids based on previous studies. We also described the latest advances in our understanding of

\footnotetext{
Abbreviations: IBD, inflammatory bowel diseases; UC, ulcerative colitis; $\mathrm{CD}$, Crohn's disease; MetaHIT, metagenomics of human intestinal tract; NIH, National Institutes of Health; HMP, human microbiome project; iHMP, integrative human microbiome project; NO, nitric oxide; AGS, human gastric adenocarcinoma cell line; HFD, high-fat diet; NOD, non-obese diabetic; QS, quorum sensing; AHL, acyl homoserine lactone; UPLC-LTQ/Orbitrap/MS/MS, ultra-high pressure liquid chromatography with a linear ion trap-high resolution Orbitrap mass spectrometry system; IBDMDB, inflammatory bowel disease multiomics database; DSS, dextran sulfate sodium; Treg, regulatory T cells; TH, T helper cells; ROR, retinoic acid-related orphan receptor; IL, interleukin; Foxp3, Forkhead box P3; DNBS, dinitrobenzene sulfonic acid; ROS, reactive oxygen species; RNS, reactive nitrogen species; PCR, polymerase chain reaction; LPS, lipopolysaccharide; TLRs, Toll-like receptors; TNBS, 2,4,6-trinitrobenzenesulfonic acid; CDI, Clostridium difficile infection; iNOS, inducible nitric oxide synthase.
}

how flavonoids and gut microbiota act independently or synergistically to influence IBD.

\section{PHYTONUTRIENTS FLAVONOIDS}

Natural compounds isolated from plants hold a large reservoir of important bioactive molecules for drugs' discovery. Phytonutrients, also called nutritive phytochemicals, are secondary metabolites accumulated in the different parts of plants $(21,22)$. The bioactive compounds have potential to be applied as therapeutic mediators in the treatment of diseases. Despite the fact that most of the phytonutrients are nonessential for humans unlike vitamins or other essential mineral micronutrients, they contribute to a significant protection against chronic diseases $(23,24)$. In traditional medical practices, the phytonutrients have been widely used not only in dietary supplements but also as therapeutic agents for the enhancement of immunity and prevention of diseases (25). On the basis of their unique properties and various structures, the phytonutrients are classified into phenolic acids, flavonoids, carotenoids, tocochromanols, and curcuminoids (26).

Flavonoids, a large family of phytonutrients, are one of the most biologically important poly-phenolic compounds, which occur ubiquitously in plant-based diets or medicinal plants, and comprise of a large group of unique compounds with oxygen-containing heterocyclic framework. The previous studies on flavonoids were focused on their curative effect because of their natural anti-oxidants, anti-carcinogenic (27, 28), anti-atherogenic (29), anti-ulcer (30), anti-thrombotic $(31,32)$, anti-inflammatory $(33,34)$, anti-allergenic (35), anticoagulant $(36,37)$, immune modulating $(34)$, anti-microbial $(38,39)$, vaso-dilatory $(40,41)$, and analgesic activities, which are summarized in Figure 1 (13, 42-44). The neuro-protective effects of flavonoids have been demonstrated in epidemiological studies to change the trajectories of degenerative diseases and improve the cognitive functions (45-49). Similarly, there are some evidences demonstrating the beneficial effect of flavonoids on cardiovascular and cerebrovascular health, either directly or indirectly by acting on the signaling molecules, biomarkers of oxidative stress, platelet function, and lipid metabolism, etc. (50-54). The anti-microbial properties of flavonoids have been extensively studied. The anti-bacterial mechanisms of flavonoids may include: damaging the structure of the cell membrane, inhibiting the synthesis of proteins, nucleic acids, or cell wall's components, and decreasing the production of energy (55-58). A growing body of evidence suggested flavonoids could inhibit carcinogenesis and the development of tumors by multiple mechanisms, such as showing antiinflammatory effects (suppressing the expression of lipoxygenase, lipoxygenase, and inducible nitric oxide synthase, etc.) $(59,60)$. Dietary flavonoids were reported to have good anti-oxidant properties as scavengers of ROS and RNS, which can strongly inhibit the progression of inflammation, including inhibiting the release of inflammatory mediators and regulating inflammationrelated signal pathways (NF-кB, AP-1, PPAR, Nrf2, and MAPK, etc.) (61). This review will focus on the beneficial effects 

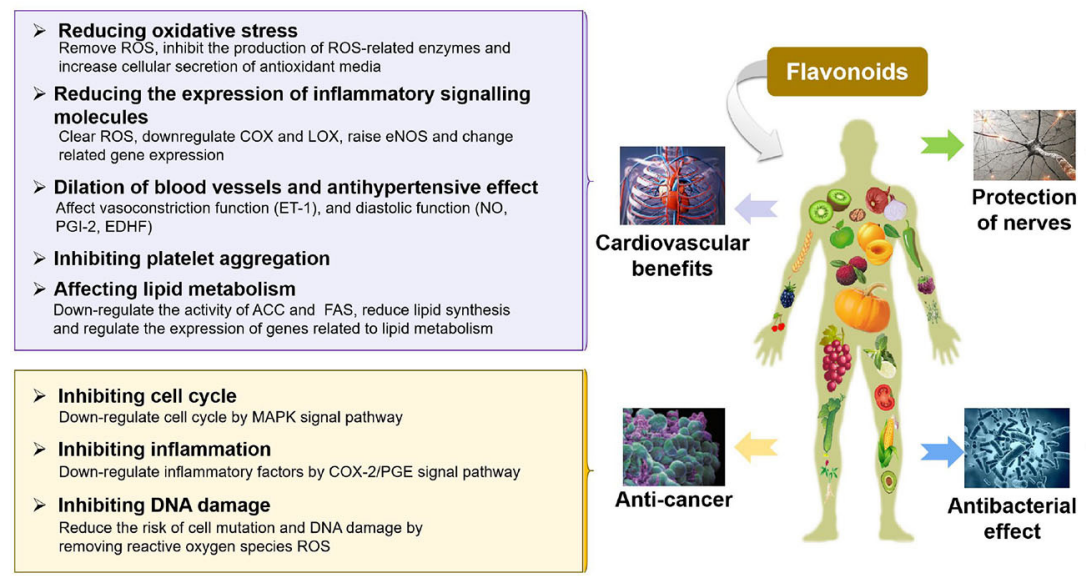

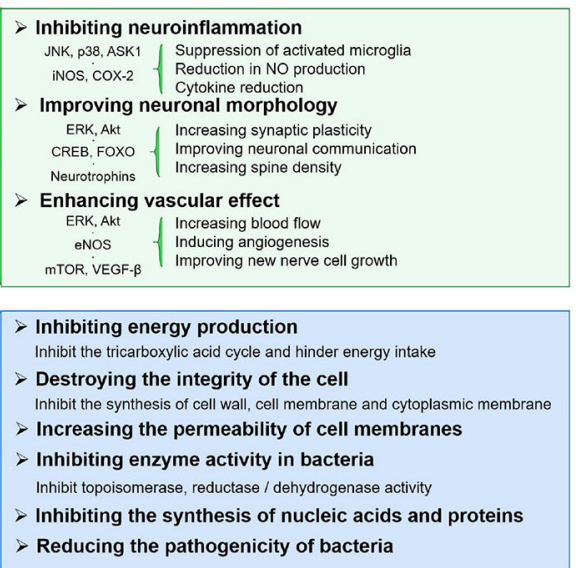

FIGURE 1 | A summary of physiological functions and their corresponding mechanisms of flavonoids.

of flavonoids on IBD, including protection of the intestinal epithelial cell barrier function, prevention of oxidative stress, and immunomodulatory properties, which will be discussed in detail in the following sections.

The flavonoids are a group of organic compounds with diverse chemical structures, characterized with structural backbone C6C3-C6 called 2-phenylbenzo-pyran, composed of two benzene rings ( $\mathrm{A}$ and $\mathrm{B}$ ) and a oxygen-containing six-membered heterocycles. In the presence of the basic skeleton of flavonoids, many types of compounds are formed due to different chemical reactions, including glycosylation, hydroxylation, methoxylation, and prenylation. Flavonoids are classified into several different types, including flavonols, flavones, isoflavones, flavan-3-ols, flavanones, and anthocyanins. These compounds sometimes also occur as glycosides, methylated derivatives, or aglycones (Figure 2) (13, 62, 63).

Flavones consist of a 2-phenyl-benzo- $\gamma$-pyrone skeleton, which is comprised of a heterocyclic pyrone ring linked with two phenyl rings. The structure of flavones appears very similar to that of the flavanones, with the major differences in the formation of linear pyran rings depending on the unsaturated $\mathrm{C} 2-\mathrm{C} 3$ bonds. The flavonoids usually occur in conjugated forms as glycosides, and the flavones are generally found with $\mathrm{O}$ glycosides at the C-3 or C-7 position, where the O-glycosidic linkage connects the sugar group with aglycone. On the other hand, the C-glycosides in flavones have received less attention, the C-glycosidic linkage is a key structural component $(64,65)$. Flavones are most commonly found in herbs such as parsley and celery, but they are also widely distributed in grains such as wheat, rye, barley, oats, sorghum, and millet. The most prevalent compounds of flavones include apigenin, baicalein, and luteolin. Their glycoside form compounds are vitexin, isovitexin, baicalin, luteolin 7-O-glucuronide, respectively. Apigenin is found in many vegetables and herbal spices, including parsley, celery, basil, chamomile, coriander, and oregano. Baicalein is a traditional Chinese herbal flavonoid found in the roots of Scutellaria baicalensis Georgi. Luteolin exists in a variety of plants, and these plants have a higher content of wholeleaf green orchid, pepper, wild chrysanthemum, honeysuckle, and perilla.

Flavonols have typical structural features within the plane of 3-hydroxyflavone base, which are distinguished according to the modifications in their different hydroxyl groups in benzene rings (62). Green tea, red grapes, onions, especially red onions, leafy vegetables, and berries are the main sources of flavonols. The highest content of flavonols has been observed in berries and onions (66). Distinguished from flavones, the flavonols have one hydroxyl group at C-3 position, which increases their instability but makes them prone to have O-glycosidic linkages in the form of O-glycosides. In addition, the flavonols are also found as O-glycosides at C-7 or other positions having hydroxyl moieties (67). The most common flavonols include quercetin, kaempferol, and myricetin, most of which form glycosidic combinations. Consequently, the glycosylation of these compounds result in enhancing their stability (68). Quercetin is widely found in various foods, including apples, black tea, berries, capers, red wine, and onions. Among them, onions have the highest content of quercetin. Kaempferol is widely distributed in different plant genera such as delphinium, camellia, barberry, tangerine peel. Myricetin is widely found in many natural plants including bayberry.

Isoflavones have a unique structure having B-ring at C-3 rather than at $\mathrm{C}-2$, which is different from the flavones. Not only that, the isoflavones also structurally resemble endogenous estrogens and have estrogenic activity by binding estrogen receptor (69). The primary natural source of isoflavones is soybean, containing various types of compounds, which are classified according to aglycones or modification by other functional groups, such as methoxylation and hydroxylation (70). Genistein, daidzein, and glycitein are the main representative compounds of isoflavones, which belong to soy phytoestrogens. Genistein is a kind of phytoestrogens derived from soybeans, mainly found in the rhizomes of the leguminous plant Genistein. Daidzein is mainly found in the root of the legume Pueraria 
<smiles>O=c1cc(-c2ccccc2)oc2ccccc12</smiles>

Flavone<smiles>C1=COC(C2CCCCC2)C=C1</smiles><smiles>Oc1cc2ccccc2[o+]c1-c1ccccc1</smiles>

Anthocyanin<smiles>O=c1c(O)c(-c2ccccc2)oc2ccccc12</smiles>

Flavonol<smiles>O=C1CC(c2ccccc2)Oc2ccccc21</smiles>

Flavanone<smiles>O=c1c(-c2ccccc2)coc2ccccc12</smiles>

Isoflavone<smiles>OC1Cc2ccccc2OC1c1ccccc1</smiles>

Flavan-3-ol

FIGURE 2 | Skeleton structure diagram of flavonoids.

lobata, the whole legume red clover, and the whole alfalfa. Notably, the equol, which is a metabolite of daidzein, is not a natural plant compound but sometimes ranked among the isoflavones (71).

Anthocyanins contain conjugated double bonds that contribute to chromophore. Moreover, the hydroxylation and methylation also determine their color phenotypes and stability with a wide range of structures varying from simple to complex compounds (72). As water-soluble pigments, the anthocyanins are usually present in cell vacuoles of the plant tissues and tend to occur mainly as glycosides. The most common sugars bonded to them are polysaccharide or monosaccharide, including glucose, rutinose, rhamnose, and xylose (73). Anthocyanins are particularly present in red fruits, some cereals, and root vegetables, such as grapes, purple grapes, blackberries, strawberries, and raspberries. The most common identified anthocyanins include cyanidin, malvidin, petunidin, pelargonidin, delphinidin, and peonidin.

Distinguished from flavones, the flavanones have saturated $\mathrm{C} 2-\mathrm{C} 3$ bonds with non-linear structure and higher bioavailability. The common flavanones include naringenin, eriodictyol, hesperetin, and sakutanetin, which can form various glycosides by the glycosylation of glucose and rhamnose. Hesperidin and naringin are the representative glycosides abundant in citrus having beneficial effects on gastrointestinal health $(63,66)$.

Flavan-3-ols, also called flavanols, have a single hydroxyl group at C-3 position instead of double bond, and lack the carbonyl group at $\mathrm{C} 4$ position. Moreover, the structures of these compounds comprise of a wide range of compounds ranging from simple monomers to condensed tannins, including
(+)-Catechin, (-)-Epicatechin, (-)-Epicatechin-3-gallate, gallocatechin, epigallocatechin, and epigallocatechin gallate (74).

\section{THE COMPLEX INTERACTION BETWEEN FLAVONOIDS AND GUT MICROBIOTA}

The ingested flavonoids, such as phytonutrients, indirectly provide energy and key elements in humans with healthpromoting effects, where the gut microbiota serves a pivotal role. The gut microbiota comprises of microorganisms residing in the human gastrointestinal tract with the total number of more than 100 trillion cells (75). Its composition varies along the digestive tract and remains plastic according to the lifestyle as well as nutritional status of host throughout the life. The gut microbiota defines the gastrointestinal functional ecology by absorption, digestion, metabolism, and excretion of flavonoids, leading to the regulation of host immune response and behavior with longterm effects (17). Moreover, the changes in the composition of gut microbiota also introduce perturbation to bioavailability and biological effect of flavonoids. Consequently, the flavonoids regulate gut microbiota with varying levels of efficacy, including the stimulation of commensal and beneficial microbiota or the inhibition of the colonization of enteric pathogens $(19,76)$. It is therefore crucial to decipher the reciprocal correlation between flavonoids and gut microbiota.

\section{Regulation of Gut Microbiota by Flavonoids}

Natural flavonoids can regulate the gut microbiota from the aspects of type and amount and ameliorate dysbiosis or maintain intestinal homeostasis, thereby maintaining the host gut health. Besides, the different types of flavonoids exhibit different efficacy 
in boosting or suppressing the growth of gut microbiota. Recent evidence suggests that the flavonoids from tart cherries substantially increase the specific Bacteroides and Collinsella. Furthermore, an in vivo study showed that gut microbiota composition changed with the consumption of tart cherries (77). In this case, the tart cherries flavonoids, such as cyanidinglycosylrutinoside and quercetin-rutinoside, showed its prebiotic effects. In other examples, in vitro digestion models, simulating anaerobic human fecal fermentation, showed that Green tea, rich in flavones and flavonols, showed multiple health-beneficial properties by increasing the populations of Lactobacilli spp. and Bifidobacteria spp. (78). The cranberry or its extracts increased the abundance of Akkermansia spp. and inhibited Bacteroides and Bifidobacteria, reducing the intestinal inflammation (79). Three plant flavonoids, including quercetin, catechin, and puerarin, were compared in a study for their regulatory functions on gut microbiota in vitro. Experimental results suggested their different capacities to regulate the abundance of Bifidobacterium spp. Moreover, the aglycones rather than glycosides were shown to influence the growth of certain species. In detail, the quercetin stimulated Firmicutes, Proteobacteria, and Actinobacteria, while puerarin increased Fusobacteria and Proteobacteria, as the consequence of increasing the richness and diversity of microbial communities (80).

Many studies have reported the effects of flavonoids on the gut microbiota. In vitro models proved that the flavonols, such as quercetin, had the following prebiotic actions: increasing the abundance of Bifidobacterium adolescentis; antiinflammatory activity by producing NO inhibitors in murine macrophage-like RAW264 cells (81); inhibiting gut pathogen Salmonella typhimurium's growth and adhesion to human gut cell line; enhancing the proliferation and adhesion of probiotic Lactobacillus rhamnosus (82). Kaempferol was reported to suppress the vacuolating cytotoxin A and cytotoxinassociated gene A translocation of Helicobacter pylori in the AGS cells model (83). Baicalein showed the similar effects (84). In vivo experiments confirmed that the oral quercetin treatment in high-fat diet (HFD)-fed mice suppressed the abundance of Verrucomicrobia and increased that of Actinobacteria, Cyanobacteria, and Firmicutes, as well as the diversity of microbiota diversity (85-87). Baicalein regulated the composition of gut microbiota via its influence on the abundance of beneficial and pathogenic bacteria (88). The treatment of genistein the abundance among the Prevotella and Akkermansia genera, particularly Prevotella copri and Akkermansia muciniphila (89). Other special in vivo models, such as the APP/PS1 transgenic mice, found that under low vitamin $\mathrm{D}$ supplementation, quercetin elevated the diversity of gut microbiota including Facklamia and Aerococcus, improving the cognitive function (90). In female perinatal non-obese diabetic (NOD) mice, the exposure of genistein showed an increase in the level of Enterobacteriales, suggesting a pro-inflammatory response (91). In other experimental settings, the flavanones in Citrus were investigated for their interference with quorum sensing (QS), which showed reduction in the levels of QS signal mediated by acyl homoserine lactone (AHL) with the downregulation of relative genes, and inhibition of biofilm formation as well as bacterium swimming and swarming motility (92). As for the flavan-3-ols, they changed the gut micro-ecology by affecting the adhesion of Lactobacilli strains to intestinal epithelial cells $(93,94)$. Anthocyanidin showed anti-bacterial activity by either killing the pathogenic bacteria or inhibiting their growth, such as Bacillus subtilis, Staphylococcus aureus, Enterococcus faecalis, and Pseudomonas aeruginosa (95). The regulation of gut microbiota by flavonoids is systematically summarized in Table 1. Previous studies were focused on the effects of the monomeric component of flavonoids on the specified strain of gut microorganisms. With the advancement in the development of metagenomics, metabolomics, proteomics, and transcriptomics, more research could focus on the in-depth regulatory mechanisms of flavonoids on gut microbiota.

\section{Effect of Gut Microbiota on the Bioaccessibility of Flavonoids}

It is well-known that the bioaccessibility of flavonoids in the human gastrointestinal tract is induced by many factors (116), including its structure, hydrolyzing enzymes throughout the gastrointestinal tract, composition of the intestinal microbiota, and transporter proteins in intestinal epithelial cells. The gut microbiota contributes to further modification and transformation of flavonoids for beneficial physiological effects. Due to its specific and vast gene pool, the intestinal microbiota has great potential in exploring the metabolites of flavonoids, and catalyzing important reactions in the intestinal tract. The gut microbiota is thought to be helpful in various metabolic reactions, including biosynthesis, catabolism, conjugation, and modification by containing various types of enzymes (117). During the conversion of flavonoids, the catalysis reaction by gut microbiota includes the following three types; hydrolysis, cleavage, and reduction. These three types are further subdivided into O-de-glycosylation, ester hydrolysis, C-ring cleavage, de-lactonization, de-methylation, de-hydroxylation, and double bond reduction (17).

The most common flavonoids are in the form of glycosides, which require the removal of attached sugars before absorption. Besides carrying glucose, galactose, arabinose, rhamnose, and xylose in the form of rhamnosides or rutinosides also contribute to the structural diversity of flavonoids, such as hesperidin, naringin, narirutin, and neohesperidin. These compounds are needed to be hydrolyzed by enzymes either from gut microbiota or human intestinal enzymes before absorption. Some enzymes can cleave glycosidic linkages present in human cells, except rhamnosidases. It has been reported that some bacteria have $\beta$-glucosidase activities in the human intestinal microbiota, which mainly include B. adolescentis, Bifidobacterium longum, Enterococcus faecalis, Bacteroides ovatus, Bacteroides uniformis, Parabacteroides distasonis, and Escherichia coli (118-124), etc. The same is true for rhamnosidase (125-129). Recent advances have reported identifying human intestinal bacterial species and strains related to flavonoid conversion, which could catalyze de-glycosylation reactions, especially O-de-glycosylation (130). For example, 22 strains of Bifidobacterium representative among the eight major species from human origin were found to 
TABLE 1 | The regulatory effect of flavonoids on the gut microbiota.

\begin{tabular}{|c|c|c|c|c|}
\hline Compounds & Model/Material & Dosage form & Major findings & References \\
\hline \multicolumn{5}{|l|}{ Flavonols } \\
\hline \multirow[t]{8}{*}{ Quercetin } & HFD Ldll-1- C57BL/6 mice & $\begin{array}{l}\text { Oral administration of } \\
\text { quercetin }\left(100 \mu \mathrm{g}_{\text {day }}^{-1}\right) \\
\text { supplement diets }\end{array}$ & $\begin{array}{l}\text { Oral quercetin treatment suppressed the abundance of Verrocomicrobia } \\
\text { and increased the abundances of Actinobacteria, Cyanobacteria, and } \\
\text { Firmicutes, as well as microbiome diversity }\end{array}$ & (86) \\
\hline & $\begin{array}{l}\text { HFD male C57BL/6J mice } \\
\text { divided into gut microbiota } \\
\text { donor and receiver }\end{array}$ & $\begin{array}{l}\text { Supplement diets with } \\
\text { aglycone quercetin }(0.05 \% \\
\text { wt/wt) at a dosage roughly } \\
\text { equal to } 80 \mathrm{mg} \mathrm{kg}^{-1} \text { day }^{-1}\end{array}$ & $\begin{array}{l}\text { The notable increase of Verrucomicrobia phylum, Verrucomicrobiae class, } \\
\text { and Akkermansia genu proved the prebiotic capacity of quercetin in gut } \\
\text { microbiota transferring from donor to receiver mice model }\end{array}$ & (87) \\
\hline & $\begin{array}{l}\text { High-fat sucrose diet (HFS) } \\
\text { Wistar rats }\end{array}$ & $\begin{array}{l}\text { Feeding quercetin ( } 30 \\
\mathrm{mg} / \mathrm{kg}^{-1} \text { day }^{-1} \text { ) as a } \\
\text { supplement }\end{array}$ & $\begin{array}{l}\text { Quercetin supplementation inhibited the growth of bacterial species } \\
\text { previously associated with diet-induced obesity (Erysipelotrichaceae, } \\
\text { Bacillus, Eubacterium cylindroides) }\end{array}$ & (85) \\
\hline & $\begin{array}{l}\text { Male APP/PS1 transgenic } \\
\text { mice (B6C3F1) }\end{array}$ & $\begin{array}{l}\text { Supplement with } 0.08 \% \\
\text { quercetin roughly equal to } \\
120 \mathrm{mg} \mathrm{kg}^{-1} \mathrm{~d}^{-1} \text { in } \\
\text { modified AIN-93G diet }\end{array}$ & $\begin{array}{l}\text { Under low vitamin D status, quercetin elevated gut microbial diversity } \\
\text { (including Facklamia and Aerococcus), and improved cognitive function }\end{array}$ & (90) \\
\hline & $\begin{array}{l}\text { Pseudomonas aeruginosa } \\
\text { strain PAO1 }\end{array}$ & $\begin{array}{l}\text { PAO1 was cultured with } \\
\text { quercetin }(16 \mu \mathrm{g} / \mathrm{ml})\end{array}$ & $\begin{array}{l}\text { Quercetin inhibited Pseudomonas aeruginosa by the factors of quorum } \\
\text { sensing, biofilm formation, and virulence }\end{array}$ & (96) \\
\hline & Staphylococcus aureus & $\begin{array}{l}\text { Alnus japonica extracts at } \\
0.1 \mathrm{mg} \mathrm{ml}^{-1}\end{array}$ & $\begin{array}{l}\text { Quercetin influenced quorum sensing hence acted as an anti-biofilm } \\
\text { compound against } S \text {. aureus }\end{array}$ & (97) \\
\hline & $\begin{array}{l}\text { Ten enteric bacteria and } \\
\text { murine macrophage-like } \\
\text { RAW264 cells }\end{array}$ & $\begin{array}{l}\text { Quercetin dissolved in } \\
\text { DMSO with final } 25 \mu \mathrm{M} \text { in } \\
1 \mathrm{ml} \text { of serum }\end{array}$ & $\begin{array}{l}\text { Several flavonols like quercetin have a prebiotic-like effect on promoting } B \text {. } \\
\text { adolescentis exerting anti-inflammatory activity by producing produces NO } \\
\text { inhibitors }\end{array}$ & (81) \\
\hline & $\begin{array}{l}\text { Probiotic Lactobacillus } \\
\text { rhamnosus, Salmonella } \\
\text { typhimurium, and Caco-2 } \\
\text { cells }\end{array}$ & $\begin{array}{l}\text { Quercetin at a final } \\
\text { concentration of } 2 \mathrm{mg} / \mathrm{ml}\end{array}$ & $\begin{array}{l}\text { Quercetin could inhibit gut pathogen Salmonella typhimurium growth and } \\
\text { adhesion to a human gut cell line, enhancing the probiotic } L \text {. rhamnosus } \\
\text { proliferation, and adhesion }\end{array}$ & (82) \\
\hline \multirow[t]{3}{*}{ Kaempferol } & $\begin{array}{l}\text { Collagen-induced arthritis } \\
\text { (CIA) model mice }\end{array}$ & $\begin{array}{l}\text { Treating mice with } \\
\text { kaempferol intragastrically } \\
\left(200 \mathrm{mg} \cdot \mathrm{kg}^{-1} \cdot \mathrm{d}^{-1}\right) \text { and } \\
\text { intraperitoneally }(20 \mathrm{mg} \text {. } \\
\left.\mathrm{kg}^{-1} \cdot \mathrm{d}^{-1}\right)\end{array}$ & $\begin{array}{l}\text { The high level of kaempferol produced distinct anti-arthritis effects in CIA } \\
\text { model mice and regulated the intestinal flora and microbiotic metabolism }\end{array}$ & (98) \\
\hline & $\begin{array}{l}\text { Helicobacter pylori and } \\
\text { human AGS cell ATCC } \\
\text { CRL-1739 }\end{array}$ & $\begin{array}{l}\text { The minimal inhibitory } \\
\text { concentration (MIC) of } \\
\text { kaempferol against } H \text {. pylori } \\
\text { was } 50 \mu \mathrm{M}\end{array}$ & $\begin{array}{l}\text { Kaempferol suppressed Helicobacter pylori vacuolating cytotoxin A and } \\
\text { cytotoxin-associated gene A translocation to AGS cells }\end{array}$ & (83) \\
\hline & Escherichia coli & $\begin{array}{l}\text { The MIC of kaempferol was } \\
25 \mu \mathrm{g} / \mathrm{ml}\end{array}$ & $\begin{array}{l}\text { Kaempferol could have great anti-Escherichia coli activity and inhibition of } \\
\text { DNA gyrase }\end{array}$ & (99) \\
\hline \multirow[t]{2}{*}{ Myricetin } & - & - & $\begin{array}{l}\text { The review summarized myricetin preclinical pharmacological activities, } \\
\text { including antimicrobial properties with multiple mechanisms }\end{array}$ & $(100)$ \\
\hline & $\begin{array}{l}\text { S. aureus infection Galleria } \\
\text { mellonella model }\end{array}$ & Myricetin at $200 \mu \mathrm{M}$ & $\begin{array}{l}\text { Myricetin possessed the influence on several factors by } S \text {. aureus, including } \\
\text { adhesion, biofilm formation, and staphyloxanthin production }\end{array}$ & (101) \\
\hline \multicolumn{5}{|l|}{ Flavones } \\
\hline \multirow[t]{2}{*}{ Apigenin } & - & - & $\begin{array}{l}\text { The review summarized studies on antimicrobial effects of apigenin as well } \\
\text { as the relationship between apigenin and human gut microbiota }\end{array}$ & (102) \\
\hline & $\begin{array}{l}\text { Human gut microbiota } \\
\text { preparation from healthy } \\
\text { female }\end{array}$ & $\begin{array}{l}\text { Apigenin at } 5,12.5,25,50 \text {, } \\
\text { and } 100 \mu \mathrm{g} / \mathrm{ml}\end{array}$ & $\begin{array}{l}\text { Apigenin effectively inhibited the growth of both Enterococcus caccae and } \\
\text { Bacteroides galacturonicus on a single strain; on the contrary, it enhanced } \\
\text { the growth of Enterococci in the community }\end{array}$ & (103) \\
\hline \multirow[t]{3}{*}{ Baicalein } & $\begin{array}{l}\text { Lactobacillus rhamnosus } \\
\text { JB3, human AGS cell } \\
\text { ATCC® CRL-1739 and } \\
\text { male C57BL/6 Helicobacter } \\
\text { pylori infections mice }\end{array}$ & $\begin{array}{l}\text { Baicalein at the } \\
\text { concentrations of } 1,0.5 \\
0.25,0.125 \text {, and } \\
0.0625 \mathrm{mM}\end{array}$ & $\begin{array}{l}\text { Baicalein and Lactobacillus spp. had a synergistic effect on eradicating } \\
\text { Helicobacter pylori infections in vitro and in vivo }\end{array}$ & (84) \\
\hline & SAMP8 mice & $\begin{array}{l}\text { Administration baicalein with } \\
200 \mathrm{mg} \mathrm{kg}^{-1} \mathrm{~d}^{-1}\end{array}$ & $\begin{array}{l}\text { Baicalein altered the abundance of six genera in SAMP8 mice, reducing } \\
\text { Mucispirillum, Parabacteroides, Bacteroides, and Sutterella, in contrast, } \\
\text { increasing Christensenellaceae }\end{array}$ & $(104)$ \\
\hline & $\begin{array}{l}\text { Male Wistar rats to establish } \\
\text { high-fat, high-sugar diet } \\
\text { (HFHSD) rat model }\end{array}$ & Baicalein at $50 \mathrm{mg} \mathrm{kg}^{-1} \mathrm{~d}^{-1}$ & $\begin{array}{l}\text { Baicalein could modulate the composition of gut microbiota via influence on } \\
\text { the abundance of beneficial and pathogenic bacteria }\end{array}$ & (88) \\
\hline
\end{tabular}


TABLE 1 | Continued

\begin{tabular}{|c|c|c|c|c|}
\hline Compounds & Model/Material & Dosage form & Major findings & References \\
\hline Chrysin & $\begin{array}{l}\text { Male CD Sprague-Dawley } \\
\text { rats induced by fructose to } \\
\text { establish metabolic } \\
\text { syndrome model }\end{array}$ & Chrysin at $100 \mathrm{mg} \mathrm{kg}^{-1} \mathrm{~d}^{-1}$ & $\begin{array}{l}\text { Chrysin could affect fructose inducing rats intestinal microbiome, especially } \\
\text { increasing Firmicutes to Bacteroidetes ratio }\end{array}$ & $(105)$ \\
\hline \multicolumn{5}{|l|}{ Isoflavones } \\
\hline \multirow[t]{3}{*}{ Genistein } & HFD male C57BL/6J mice & $\begin{array}{l}\text { HFD with } 0.2 \% \text { genistein } \\
\text { approximately } 3 \mathrm{mg} \mathrm{kg}^{-1} \\
\mathrm{~d}^{-1}\end{array}$ & $\begin{array}{l}\text { The abundance among the Prevotella and Akkermansia genera, particularly } \\
\text { Prevotella copri and Akkermansia muciniphila under the treatment of } \\
\text { genistein }\end{array}$ & (89) \\
\hline & $\begin{array}{l}\text { Female non-obese diabetic } \\
\text { (NOD) mice }\end{array}$ & $\begin{array}{l}\text { Oral administration of } \\
\text { genistein at } 20 \mathrm{mg} \mathrm{kg}^{-1} \mathrm{~d}^{-1}\end{array}$ & $\begin{array}{l}\text { Perinatal genistein exposed NOD mice exhibited an increased level of } \\
\text { Enterobacteriales that suggested a pro-inflammatory response }\end{array}$ & (91) \\
\hline & $\begin{array}{l}\text { Germ-free } R A G 2^{-/-} \\
\text {athymic female mice } \\
\text { established breast cancer } \\
\text { orthotopic xenografts }\end{array}$ & $\begin{array}{l}\text { Feeding a special corn oil } \\
\text { customized diet } \\
\text { (genistein- } 0.25 \mathrm{~g} / \mathrm{Kg} \text { ) }\end{array}$ & $\begin{array}{l}\text { In the genistein-treated humanized mice, the abundance of genera } \\
\text { Lactococcus and Eubacterium increased }\end{array}$ & $(106)$ \\
\hline \multicolumn{5}{|l|}{ Flavan-3-ols } \\
\hline \multirow[t]{2}{*}{ Epicatechin } & -- & -- & $\begin{array}{l}\text { This review introduced four main catechins found in green tea, including } \\
(-) \text {-epicatechin (EC), (-)-epicatechin-3-gallate (ECG), (-)-epigallocatechin } \\
\text { (EGC), and (-)-epigallocatechin-3-gallate (EGCG), had antimicrobial effects, } \\
\text { such as damage to the cell membrane, inhibition of enzyme activity }\end{array}$ & $(107)$ \\
\hline & $\begin{array}{l}\text { Lactobacillus acidophilus } \\
\text { strains KCTC } 3140, \text { KCTC } \\
\text { 3146, KCTC 3154, and } \\
\text { KCTC3179 }\end{array}$ & $\begin{array}{l}\text { Epicatechin was quantified } \\
\text { as } 6.36 \mu \mathrm{g} / \mathrm{ml} \text { in the } \\
\text { Bulnesia sarmienti aqueous } \\
\text { extracts }\end{array}$ & $\begin{array}{l}\text { (-)-Epicatechin from Bulnesia sarmienti aqueous extract as the prebiotic } \\
\text { active components enhanced the growth of four Lactobacillus acidophilus } \\
\text { isolated from rat, pig, chicken, and human gut }\end{array}$ & $(108)$ \\
\hline Gallocatechin & $\begin{array}{l}\text { Cystic Fibrosis patients fecal } \\
\text { samples with ingesting } \\
\text { flavonoid }\end{array}$ & -- & $\begin{array}{l}\text { Gallocatechin was found to be correlated with the family Actinomycetaceae } \\
\text { (Actinobacteria) }\end{array}$ & $(109)$ \\
\hline \multicolumn{5}{|l|}{ Flavanones } \\
\hline \multirow[t]{2}{*}{ Naringenin } & $\begin{array}{l}\text { Ruminococcus gauvreauii, } \\
\text { Bifidobacterium } \\
\text { catenulatum, and } \\
\text { Enterococcus caccae }\end{array}$ & $\begin{array}{l}\text { Naringenin in a final } \\
\text { concentration of } 200,150 \text {, } \\
100 \text {, and } 50 \mu \mathrm{g} / \mathrm{ml} \text { in } \\
\text { strain-specific broth } \\
\text { containing } 1 \% \text { DMSO }\end{array}$ & $\begin{array}{l}\text { Naringenin had the effect on the growth and genetic expression of three gut } \\
\text { microbes, with the result of increasing Bifidobacterium catenulatum, } \\
\text { inhibiting Enterococcus caccae, and no affection to Ruminococcus } \\
\text { gauvreauii, both changing to the gene expression for all three strains }\end{array}$ & $(110)$ \\
\hline & $\begin{array}{l}\text { Escherichia coli O157:H7 } \\
\text { ATCC } 43895 \text { and Vibrio } \\
\text { harveyi MM32 }\end{array}$ & $\begin{array}{l}\text { Naringenin at } 6.25,12.5 \\
25,50, \text { and } 100 \mu \mathrm{g} / \mathrm{ml}\end{array}$ & $\begin{array}{l}\text { Naringenin had the potential to be a inhibitor of autoinducer-mediated } \\
\text { cell-cell signaling for modulating the Escherichia coli biofilm and Vibrio } \\
\text { harveyi MM32 virulence }\end{array}$ & $(111)$ \\
\hline Eriodictyol & $\begin{array}{l}\text { S. aureus USA300 strain } \\
\text { ATCC BAA-1717 and } \\
\text { human alveolar epithelial cell } \\
\text { line (ATCC CCL185) }\end{array}$ & $\begin{array}{l}\text { The MIC of eriodictyol } \\
\text { against } S \text {. aureus was } \\
512 \mu \mathrm{g} / \mathrm{mL}\end{array}$ & $\begin{array}{l}\text { Eriodictyol had the potential against } S \text {. aureus infection via downregulating } \\
\text { alpha-hemolysin at the levels of expression and transcription }\end{array}$ & $(112)$ \\
\hline \multicolumn{5}{|l|}{ Anthocyanins } \\
\hline \multirow[t]{2}{*}{$\begin{array}{l}\text { Malvidin-3- } \\
\text { glucoside }\end{array}$} & $\begin{array}{l}\text { C57BL/6J male mice } \\
\text { induced by DSS }\end{array}$ & $\begin{array}{l}\text { The AIN-93M containing } \\
\text { malvidin-3-glucoside at } \\
24 \mathrm{mg} \mathrm{kg}^{-1} \text { diet }\end{array}$ & $\begin{array}{l}\text { Malvidin-3-glucoside reduced the abundance of pathogenic bacteria, such } \\
\text { as Ruminococcus gnavus, and restored the Firmicutes/Bacteroidetes ratio }\end{array}$ & $(113)$ \\
\hline & Health human fecal samples & $\begin{array}{l}\text { Malvidin-3-glucoside was } \\
\text { inoculated at } 20 \mathrm{mg} / \mathrm{L} \text { and } \\
200 \mathrm{mg} / \mathrm{L}\end{array}$ & $\begin{array}{l}\text { Malvidin-3-glucoside tested significantly enhancing the growth of } \\
\text { Bifidobacterium spp. and Lactobacillus-Enterococcus spp. }\end{array}$ & $(114)$ \\
\hline $\begin{array}{l}\text { Cyanidin-3-O- } \\
\text { glucoside }\end{array}$ & $\begin{array}{l}\text { Male Wistar rats induced by } \\
\text { 3-chloro-1,2-propanediol }\end{array}$ & $\begin{array}{l}\text { The diet with } \\
\text { supplementation of } 500 \\
\text { mg/kg } \\
\text { cyanidin-3-O-glucoside }\end{array}$ & $\begin{array}{l}\text { Cyanidin-3-O-glucoside was found to increase the relative abundance of } \\
\text { Lachnospiraceae and Actinobacteria and might have beneficial regulating } \\
\text { the communities of gut microbiota }\end{array}$ & $(115)$ \\
\hline
\end{tabular}

have the ability of bio-conversion of soy isoflavones (120). Tao et al. characterized and isolated intestinal bacteria from the human feces sample and investigated their ability to convert buddleoside by using UPLC-LTQ/Orbitrap/MS/MS, and found four strains showing more powerful conversion capability (128). After releasing their aglycones, the flavonoids can be metabolized by phase II biotransformation enzymes into glucuronidated, sulfated and methylated products (131), which then require specific transferases, including glucuronyl-transferase, phenolsulfo-transferase, and acetyl-transferase. The catabolic reactions of flavonoids include the removal of methyl ethers, opening of carbon rings, and breaking of C-C bonds. These catabolic 
reactions are regulated by the enzymatic activities of anaerobic bacteria, such as Clostridium and Coriobacteriaceae (17). The phenolic rings of flavonoids often contain methoxy groups, and some strains have the ability to $\mathrm{O}$-demethylate, such as Bacterium Bautia sp. MRG-PMF1 and Eubacterium limosum (132-135). Recently, Feng et al. (136) have summarized that some intestinal bacteria could metabolize flavonoids in various metabolites with cleaved rings enzymes, mainly from Enterococcus casseliflavus, Eubacterium ramulus, Clostridium orbiscindens sp. nov. These microbe-derived metabolites were reported to possess multiple bioactivities in different metabolic pathways (136-138). Table 2 lists some main flavonoid-converting enzymes related to the human gut bacteria.

\section{GUT MICROBIOTA AND IBD}

Inflammatory bowel disease is an autoimmune intestinal disorder, having UC and CD as the most common phenotype, characterized with the intermittent episodes having relapse and clinical remission, potentially causing intestinal injury and dysfunction. The UC is characterized with continuous inflammation, which is limited to the mucosa and extends from the rectum to a variable degree in the colon. The pathological features of UC are micro-abscesses, in which the neutrophils infiltrate into the lamina propria and intestinal crypts. Other histological feature includes the depletion of goblet cells. Unlike UC, the CD is characterized with the segmental and chronic inflammation and sharp demarcation between bowel segments, accompanied by the pathological features of transmural inflammation, granulomatous inflammation, and narrow or penetrating ulcers, involving any site of the gastrointestinal tract (140). The human gastrointestinal tract contains a complex and diverse microbial community, making a strong symbiotic relationship with the host. The gut homeostasis needs the interaction between commensal microbiota and host immune system (141). At present, the gut microbiota is reported to have multiple important functions, including the synthesis of essential vitamins, fermentation and digestion of other nutrients, and protection of the gastrointestinal from colonization by pathobionts. In general, the gut microbiota sustains a relative balance, which can be changed by environmental factors, such as anti-biotic exposure and diet (142-144). The gut microbiota is a key regulator of health and disease, which is, sometimes considered as an essential "organ" that provides nourishment, regulates the epithelial development, and instructs the innate immunity (145). However, it has also been linked to the risk of a variety of diseases, including the metabolic diseases, IBD, colorectal cancer, and allergic diseases (146). The excellent studies (Table 3), recently published by HMP and iHMP launched by NIH, have comprehensively characterized the metabolic changes in the microbiota and host immune responses during the IBD using multi-omics data, including macrogenomics, macro-transcriptomics, and macro-proteomics. All the relevant data is deposited in the Inflammatory Bowel Disease Multi-omics Database (IBDMDB) (3). This showed that the $\mathrm{IBD}$, which is a heterogeneous disease, is caused by the genetic variabilities as well as the complex interactions between intrinsic host factors and environmental factors (147). However, the exact mechanism of pathogenesis of IBD is still remained to be elucidated, and there is no consensus theory according to existing literature. In the following, the complex interactions between IBD and gut microbiota are discussed to serve as primary targets for potential therapeutic strategies (Figure 3).

\section{IBD and Microbial Dysbiosis}

Studies have shown that cesarean section, non-breastfeeding, too clean life urbanization and anti-biotic abuse may lead to a lack of exposure to microorganisms in early life, resulting in the loss of adverse regulatory pathways, leading to an overactive immune response to the symbiotic gut microbiota. When the steady-state balance between the host and its microbial content is disrupted, it is called dysbiosis, which is considered to be closely related to IBD in some studies on animal models and humans. This uncontrolled intestinal immune response to the bacterial antigens leads to the activation of leukocytes and epithelial cells, causing the production of numerous cytokines and chemokines, thereby triggering a series of oxidation reactions and inflammatory responses (156). Differences in the compositions of intestinal microbiota exist between IBD patients and healthy people. Similarly, Rehman et al. profiled the bacterial community by analyzing 89 mucosal biopsies samples from German, Lithuanian, and Indian individuals and found that the Faecalibacteria and Papillibacter, which belong to the Clostridium leptum subgroup, served as reliable microbiota-based biomarkers (150). The relative abundances of Firmicutes and Enterobacteriaceae were also found to be correlated with the IBD (157). Recent metagenomic analyses also revealed the effects of the gut microbiota's dysbiosis at the strain level, demonstrating Enterococcus faecalis as an inflammatory genotype from UC patients (149). Moreover, the association between Malassezia and $\mathrm{CD}$ has also been demonstrated in the dextran sulfate sodium (DSS) -induced mouse models (158). M. restricta mainly triggers innate inflammation through CARD9 and is recognized by antifungal anti-bodies in patients with $\mathrm{CD}$; it will produce strong inflammatory cytokines from innate cells carrying IBD-related CARD9 polymorphisms and aggravate colitis in mice model. Among various chemically induced colitis models, the DSSinduced colitis model is widely used because of its simplicity and many similarities with human UC. The acute, chronic, and recurring models of intestinal inflammation can be achieved by modifying the concentration and frequency of DSS.

\section{IBD and Immune Response}

The host immune system and indigenous gut microbiota coevolve with each other, maintaining a rigid balance between tolerance to the symbiotic bacteria and responding to the threat from pathogenic bacteria (159). The balance of $\mathrm{T}_{\text {reg }} / \mathrm{T}_{\mathrm{H} 17}$ with pro-inflammatory and anti-inflammatory cytokines is essential for efficient host gut homeostasis and is directly affected by the gut microbiota, which has been demonstrated in mouse models $(160,161)$. Under the transcriptional regulation of retinoic acidrelated orphan receptor (ROR)- $\gamma t$, the $\mathrm{T}_{\mathrm{H} 17}$ mediates effector functions, which is a characteristic feature for the production of 
TABLE 2 | Enzymes and microorganisms involved in the transformation of flavonoids by human gut bacteria.

\begin{tabular}{|c|c|c|c|c|}
\hline Reaction & Enzymes & Species/Strain & Major findings & References \\
\hline \multirow[t]{11}{*}{ Deglycosylation } & $\beta$-Glucosidase & $\begin{array}{l}\text { Bifidobacterium Adolescentis } \\
\text { Bifidobacterium animalis subsp lactis } \\
\text { Bifidobacterium bifidum } \\
\text { Bifidobacterium breve } \\
\text { Bifidobacterium catenulatum } \\
\text { Bifidobacterium longum } \\
\text { Bifidobacterium infantis }\end{array}$ & $\begin{array}{l}\text { Screened } 22 \text { strains of Bifidobacterium representative among } \\
\text { eight major species from the human origin for their ability to } \\
\text { bioconversion of soy isoflavones } \\
\text { Screened five Bifidobacteria strains from the human origin for their } \\
\text { specific beta-glucosidase activity and their metabolic competence } \\
\text { in dietary flavonoids analyzed by high-performance liquid } \\
\text { chromatography separations }\end{array}$ & (118) \\
\hline & & Bifidobacterium Pseudocatenulatum & $\begin{array}{l}\text { Selected two Bifidobacterium strains among } 46 \text { lactic acid } \\
\text { bacteria for their relatively high beta-glucosidase activities with } \\
\text { finding coding genes and successfully constructed several } \\
\text { bifidobacteria expression vectors }\end{array}$ & (121) \\
\hline & & $\begin{array}{l}\text { Bifidobacterium lactis } \\
\text { Lactobacillus plantarum } \\
\text { Lactobacillus casei } \\
\text { Lactobacillus acidophilus }\end{array}$ & $\begin{array}{l}\text { Investigated enzymatic potential of Bifidobacteria and } \\
\text { Lactobacillus for converting delphinidin and malvidin glycosides } \\
\text { and screened their } \beta \text {-glucosidase activity }\end{array}$ & (119) \\
\hline & & $\begin{array}{l}\text { Lactobacillus mucosae INIA P50 } \\
\text { Lactococcus lactis MG1363 }\end{array}$ & $\begin{array}{l}\text { The genes from Lactobacillus mucosae were cloned in } \\
\text { Lactococcus lactis with special vectors, and their high } \\
\text { beta-glucosidase activities and abilities to efficiently catalyze were } \\
\text { shown }\end{array}$ & $(124)$ \\
\hline & & $\begin{array}{l}\text { Lactobacillus casei LP71 } \\
\text { Lactobacillus plantarum E112 } \\
\text { Lactobacillus rhamnosus E41 } \\
\text { Bifidobacterium } \\
\text { pseudocatenulatum C35 }\end{array}$ & $\begin{array}{l}\text { Fermented eight lactobacilli and two bifidobacteria strains and } \\
\text { monitored their beta-glucosidase activities }\end{array}$ & (123) \\
\hline & & Lactic acid bacteria & $\begin{array}{l}\text { Based on biochemical and genomic information, systematically } \\
\text { summarized lactic acid bacteria having the glucosidase activities } \\
\text { and the function of hydrolyzing plant metabolite glycoconjugates }\end{array}$ & (122) \\
\hline & Rhamnosidase & $\begin{array}{l}\text { Escherichia sp. } 4 \\
\text { Escherichia sp. } 34 \\
\text { Enterococcus sp. } 45 \\
\text { Bacillus sp. } 46\end{array}$ & $\begin{array}{l}\text { Characterized and isolated the intestinal bacteria from the fecal } \\
\text { sample and investigated their conversion of bundle side using } \\
\text { UPLC-LTQ/Orbitrap/MS/MS; as a result, four strains showed } \\
\text { enzyme activities }\end{array}$ & (128) \\
\hline & & $\begin{array}{l}\text { Bifidobacterium longum R0175 } \\
\text { Lactobacillus rhamnosus subsp. } \\
\text { Rhamnosus NCTC } 10302\end{array}$ & $\begin{array}{l}\text { Investigated the ability of two probiotic bacteria to catabolise } \\
\text { flavanones by HPLC-HR-MS }\end{array}$ & (129) \\
\hline & & Bifidobacterium pseudocatenultum & $\begin{array}{l}\text { Investigated that bifidobacteria if could hydrolyze rutinosides by } \\
\text { screening } 33 \text { strains and Bifidobacterium pseudocatenulatum } \\
\text { showed the possibility in agreement with a putative } \\
\text { alpha-I-rhamnosidase }\end{array}$ & (126) \\
\hline & & Enterococcus avium EFEL009 & $\begin{array}{l}\text { The strain was isolated and identified from the human fecal } \\
\text { samples, and it showed enzymatic activities under anaerobic } \\
\text { conditions }\end{array}$ & (127) \\
\hline & & $\begin{array}{l}\text { Bacillus } s p .52 \\
\text { Bacteroides sp. 45, 42, } 22 \\
\text { Veillonella sp. } 32\end{array}$ & $\begin{array}{l}\text { Five human intestinal bacteria strains were found related to the } \\
\text { deglycosylated route of rutin and showed } \alpha \text {-I-rhamnosidase and } \\
\beta \text { - } d \text {-glucosidase activities with using UPLC-Q-TOF/MS }\end{array}$ & (125) \\
\hline \multirow[t]{4}{*}{ Demethylation } & - & Bacterium Bautia sp MRG-PMF1 & $\begin{array}{l}\text { Studied the capability of the human intestinal bacterium } \\
\text { MRG-PMF1 to the biotransformation and metabolizing of } \\
\text { poylmethoxyflavones }\end{array}$ & (133) \\
\hline & & & $\begin{array}{l}\text { MRG-PMF1 had the metabolic function to curcumin and other } \\
\text { curcuminoids }\end{array}$ & $(134)$ \\
\hline & & & $\begin{array}{l}\text { MRG-PMF1 could biotransform poylmethoxyflavones to various } \\
\text { demethylated metabolites }\end{array}$ & (135) \\
\hline & & Eubacterium limosum & $\begin{array}{l}\text { The intestinal bacterium was used to test the capacity of } \\
\text { O-demethylation and degradation of flavonoids }\end{array}$ & (132) \\
\hline
\end{tabular}


TABLE 2 | Continued

\begin{tabular}{|c|c|c|c|c|}
\hline Reaction & Enzymes & Species/Strain & Major findings & References \\
\hline \multirow[t]{3}{*}{ Ring cleavage } & - & $\begin{array}{l}\text { Enterococcus casseliflavus } \\
\text { Eubacterium ramulus } \\
\text { Clostridium orbiscindens sp. nov. }\end{array}$ & $\begin{array}{l}\text { The review summarized the metabolism capabilities of different } \\
\text { flavonoids to be the ring cleavage metabolites by the intestinal } \\
\text { bacterial and their metabolic pathways }\end{array}$ & $(136)$ \\
\hline & & Bacterium CG19-1 & $\begin{array}{l}\text { Newly isolated human intestinal bacterium CG19-1 from fecal } \\
\text { suspensions was identified to convert puerarin }\end{array}$ & $(137)$ \\
\hline & - & $\begin{array}{l}\text { Eggerthella lenta rK3 } \\
\text { Flavonifractor plautii aK2 }\end{array}$ & $\begin{array}{l}\text { Isolated two bacterial strains from the human fecal suspension that } \\
\text { were characterized to associate with the conversion of catechins }\end{array}$ & $(138)$ \\
\hline $\begin{array}{l}\text { Double bond } \\
\text { reduction }\end{array}$ & - & Clostridium orbiscindens & $\begin{array}{l}\text { An anaerobic bacteria degrading quercetin isolated from human } \\
\text { feces were identified by } 16 \mathrm{~S} \text { rRNA gene sequence analysis and } \\
\text { could transform several flavonoids under strictly anoxic conditions }\end{array}$ & (139) \\
\hline
\end{tabular}

TABLE 3 | The correlation between gut microbe and IBD in some research with various methods.

\begin{tabular}{|c|c|c|c|}
\hline Methodology & Study subject & Major findings & References \\
\hline $\begin{array}{l}\text { Integrating taxonomic, } \\
\text { metagenomic, } \\
\text { metatranscriptomic, } \\
\text { metaproteomic, and } \\
\text { metabolic data }\end{array}$ & $\begin{array}{l}\text { The Inflammatory Bowel Disease } \\
\text { Multi'omics Database (IBDMDB) for } \\
1,785 \text { stool samples, } 651 \text { intestinal } \\
\text { biopsies, and } 529 \text { quarterly blood } \\
\text { samples }\end{array}$ & $\begin{array}{l}\text { Demonstrate an increase in facultative anaerobes at the expense of } \\
\text { obligate anaerobes, and molecular disruptions in microbial transcription } \\
\text { (for example, among clostridia), metabolite pools (acylcarnitines, bile } \\
\text { acids, and short-chain fatty acids), and levels of antibodies in host } \\
\text { serum }\end{array}$ & $(3,10)$ \\
\hline Healthy patient's biopsies & $\begin{array}{l}\text { Five sites (cecum-ascending, } \\
\text { transverse, descending, sigmoid, } \\
\text { rectum) for healthy patient's biopsies }\end{array}$ & $\begin{array}{l}\text { The composition of the microbiota in IBD patients differed from that of } \\
\text { healthy controls. The high rate of bacterial DNA in the blood samples } \\
\text { indicated translocation in inflammatory bowel disease }\end{array}$ & $(148)$ \\
\hline $\begin{array}{l}\text { Whole-genome shotgun } \\
\text { sequencing }\end{array}$ & $\begin{array}{l}\text { Fecal DNA extracts from } 13 \text { healthy } \\
\text { donors and } 16 \text { UC and } 8 \text { CD patients }\end{array}$ & $\begin{array}{l}\text { Enterococcus faecium strains derived from UC patients displayed an } \\
\text { inflammatory genotype that caused colitis }\end{array}$ & $(149)$ \\
\hline $\begin{array}{l}\text { 16S rRNA gene (RNA and } \\
\text { DNA) pyrosequencing }\end{array}$ & $\begin{array}{l}\text { Mucosal biopsies sampled from } \\
\text { individuals of German, Lithuanian, } \\
\text { and Indian origins }\end{array}$ & $\begin{array}{l}\text { Faecalibacteria and Papillibacter belonged to Clostridium leptum } \\
\text { subgroup had the respect to serving as reliable microbiomarkers }\end{array}$ & $(150)$ \\
\hline $\begin{array}{l}\text { 16S rRNA gene sequencing } \\
\text { and Immunochip }\end{array}$ & Intestinal biopsies samples & $\begin{array}{l}\text { Identified and confirmed a significant association between NOD2 risk } \\
\text { allele count and increased relative abundance of Enterobacteriaceae, } \\
\text { and } 48 \text { additional IBD-related SNPs had directionality of their } \\
\text { associations with bacterial taxa }\end{array}$ & $(151)$ \\
\hline $\begin{array}{l}\text { 16S rRNA gene sequencing } \\
\text { and microarray }\end{array}$ & $\begin{array}{l}\text { Patients who had surgical } \\
\text { management of UC and all patients } \\
\text { had ileal pouch-anal anastomosis } \\
\text { surgery at least } 1 \text { year prior to biopsy } \\
\text { collection }\end{array}$ & $\begin{array}{l}\text { Activation of host processes was inversely correlated with Sutterella, } \\
\text { Akkermansia, Bifidobacteria, and Roseburia abundance and positively } \\
\text { correlated with Escherichia abundance }\end{array}$ & $(152)$ \\
\hline $\begin{array}{l}16 S \text { rDNA sequencing and } \\
\text { transcriptome analyses }\end{array}$ & $\begin{array}{l}\text { Dextran sulfate sodium induced } \\
\text { specific pathogen-free (SPF) and } \\
\text { germ-free (GF) mice }\end{array}$ & $\begin{array}{l}\text { Gut microbes were affected by diet and interfered with intestinal } \\
\text { permeability and intestinal inflammation development }\end{array}$ & $(153)$ \\
\hline Metabolomics & $\begin{array}{l}\text { The Human Metabolome Database } \\
\text { (HMDB) }\end{array}$ & $\begin{array}{l}\text { Established correlations between microbial composition and specific } \\
\text { bacterial metabolic pathways; assessed the effects of small molecule } \\
\text { products on IBD pathogenesis }\end{array}$ & $(154)$ \\
\hline Gut microorganisms & $\begin{array}{l}\text { Two thousand three hundred and } \\
\text { seventy-nine participants from two } \\
\text { population-based cohorts (LLD and } \\
\text { 500FG) and two disease cohorts (IBD } \\
\text { and 300OB) }\end{array}$ & $\begin{array}{l}\text { Identified several key species and pathways in IBD and obesity; } \\
\text { provided evidence that altered microbial abundances in disease could } \\
\text { influence their co-abundance relationship }\end{array}$ & $(155)$ \\
\hline
\end{tabular}

signature cytokines, including interleukin (IL)-17, IL-21, IL-22, IL-23, and IL-25, which, in turn, induce other pro-inflammatory cytokines and chemokines, promoting tissue inflammation. The $\mathrm{T}_{\text {reg }}$ cells are regulated by the transcription factor forkhead box P3 (Foxp3), and can be divided into natural and induced

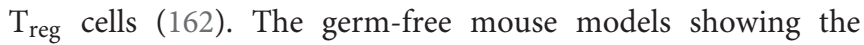
symptoms of intestinal immune deficits demonstrated that the microbiota was required for the development of intestinal immune system (163). The increase in the intestinal $\mathrm{T}_{\mathrm{H} 17}$ and $\mathrm{T}_{\mathrm{H} 2}$ cells and decrease in the ROR $\gamma \mathrm{t}$ Treg cells were reported in the germ-free mice being supplemented with the IBD microbiota (164). Some species in the gut microbiota directly or indirectly participate in the inflammatory processes. Their pathogenetic effect is based on the induction of proinflammatory immune cells, followed by the effector function. A number of studies have identified several specific commensal bacteria 


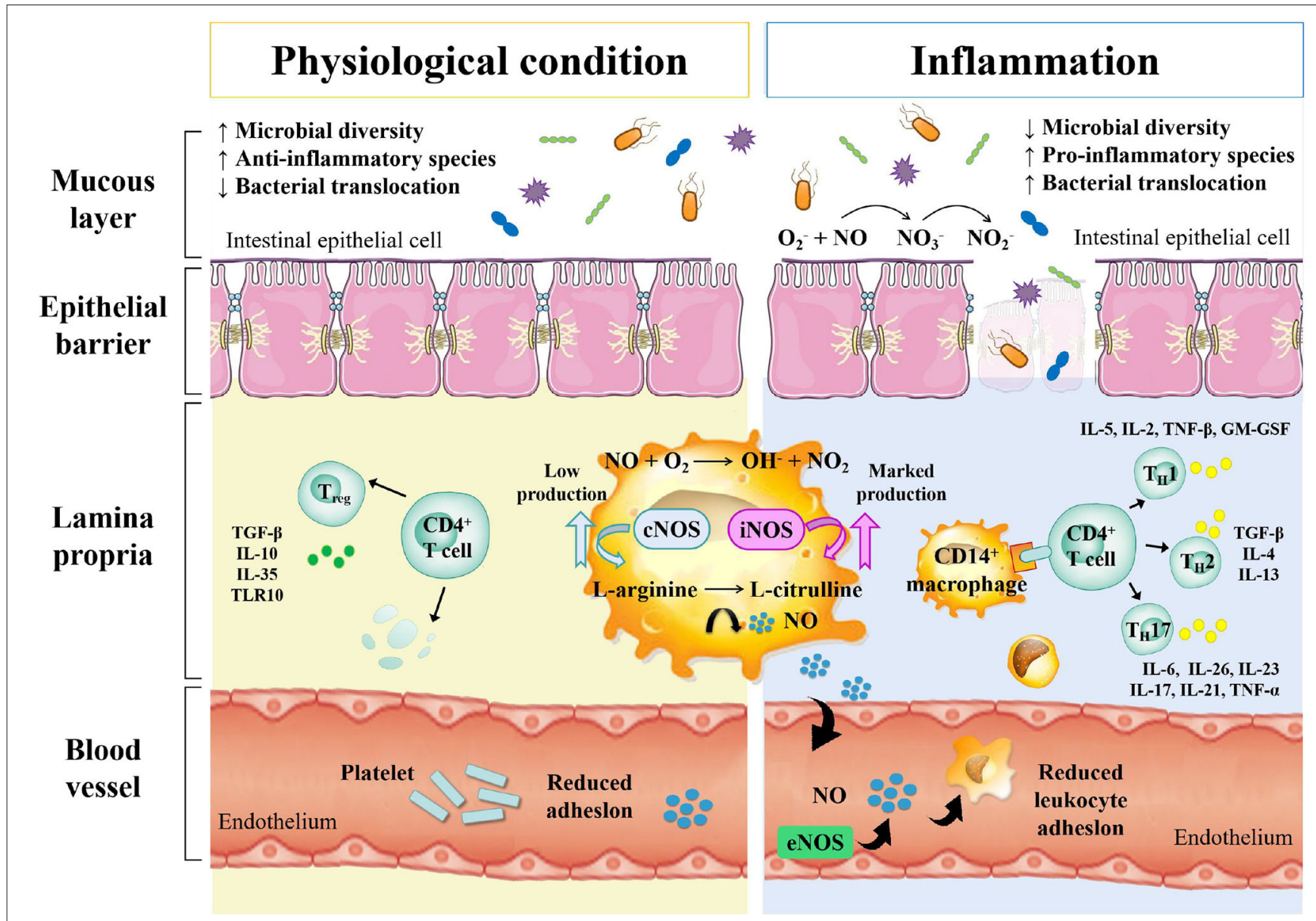

FIGURE 3 | The relationship between gut microbe and IBD.

with intestinal $\mathrm{T}_{\text {reg }}$-inducing capacity, such as Bacteroides fragilis and Clostridium $(163,165,166)$. Interestingly, a study found the commensal bacterium, involved in the pathogenesis of $\mathrm{CD}$, produced the anti-inflammatory proteins, revealing its antiinflammatory effect by inhibiting the NF- $\mathrm{KB}$ pathway in the dinitrobenzene sulfonic acid (DNBS)-induced colitis mouse models (167). On the other hand, a study found that the total mucosa-associated bacteria increased in the UC and CD samples from the normal intestinal epithelium, while the quantity and abundance of Akkermansia muciniphila reduced by many fold (168). Another study found that the human commensal bacterial strain, B. fragilis, had a protective effect in DSS-induced mouse models of experimental colitis (169).

\section{IBD and Barrier Disruption}

The alterations in the gut microbiota resulted from the increase in the nitrosative and oxidative stress in the intestinal environment during IBD include the decrease in microbial diversity and the increase in the relative abundance of facultative anaerobe (7). One of the typical symptoms of IBD pathology is the dysfunction of intestinal barrier with increasing intestinal permeability, which results from disruption of tight junction proteins and release of pro-inflammatory mediators, including ROS and RNS (170). As a result, the aberrant mucosal immune response affects the genetically predisposed individuals, causing the pathologic alterations in their intestinal microbiota (171). In healthy people, the normal intestinal microbiota inhabiting the colon mucus is relatively stable, which does not trigger the inflammatory response. This is due to the inner and outer mucus layers of colon, which are consisted of mucins, trefoil peptides, immunoglobulins and other proteins, consequently maintaining the barrier integrity (172). The anti-microbial proteins also play an important role in the prevention of the overgrowth of pathogenic strains (173). The dysregulation of mucosal immune system usually results in the pathogenic immune response to the intestinal commensal microbiota (174). Vrakas et al. collected blood and tissue biopsy samples from the active/inactive UC and $\mathrm{CD}$ adult patients, as well as healthy individuals, and determined their composition of gut microbiota using real-time quantitative reverse transcription PCR. The result showed that in comparison with healthy controls, the total bacterial DNA concentration levels were higher in the IBD patients with the increase in Bacteroides spp. and reduction in Clostridium leptum group and Faecalibacterium prausnitzi (148). 
TABLE 4 | The affection of flavonoids on gut microbiota and IBD.

\begin{tabular}{|c|c|c|c|c|}
\hline Compound & Animal model & Dosage form & Major findings & References \\
\hline Naringenin & $\begin{array}{l}\text { DSS-induced colitis male } \\
\text { BALB/c mice }\end{array}$ & $\begin{array}{l}\text { Feeding a diet containing } \\
0.3 \% \text { (wt:wt) naringenin }\end{array}$ & $\begin{array}{l}\text { Feeding naringenin attenuated the increased DAl and colon shortening and } \\
\text { tended to suppress the increased cytokine expression }\end{array}$ & (175) \\
\hline \multirow[t]{3}{*}{ Kaempferol } & $\begin{array}{l}\text { Coculture model of intestinal } \\
\text { epithelial cells and intestinal } \\
\text { microvascular endothelial cells }\end{array}$ & Kaempferol at $80 \mu \mathrm{M}$ & $\begin{array}{l}\text { Kaempferol alleviated the IL-8 secretion, and barrier dysfunction of the } \\
\text { Caco-2 monolayer, had a protective effect against barrier dysfunction via } \\
\text { preventing the activation of the NF-kB signaling pathway }\end{array}$ & (177) \\
\hline & $\begin{array}{l}\text { DSS-induced colitis male } \\
\text { C57BL/6 mice }\end{array}$ & $\begin{array}{l}\text { Rape bee pollen extracts at } \\
21.2 \text { and } 10.6 \mathrm{~g} / \mathrm{kg} \\
\text { (containing kaempferol } \\
19.87 \mathrm{mg} / \mathrm{g} \text { ) }\end{array}$ & $\begin{array}{l}\text { The kaempferol in rape bee pollen extracts altered the gut microbial } \\
\text { structure of colitis mice, significantly reduced the abundances of } \\
\text { Allobaculum and Bacteroides and markedly increased the abundance of } \\
\text { Lactobacillus }\end{array}$ & (178) \\
\hline & Female C57BL/6J mice & $\begin{array}{l}0.1 \text { and } 0.3 \% \text { kaempferol } \\
\text { diets }\end{array}$ & $\begin{array}{l}\text { Kaempferol decreased plasma levels of NO and PGE2, suppressed colonic } \\
\text { mucosa MPO activity, and up-regulated goblet cell function marker TFF3 } \\
\text { mRNA }\end{array}$ & (179) \\
\hline & $\begin{array}{l}\text { DSS induced colitis C57BL/6J } \\
\text { male mice }\end{array}$ & Baicalin at $20 \mathrm{mg} / \mathrm{kg}$ & $\begin{array}{l}\text { The target cells of activated T cells in the gut, STAT4 transcription in CECs } \\
\text { was downregulated by baicalin }\end{array}$ & (181) \\
\hline \multirow[t]{2}{*}{ Astragalin } & $\begin{array}{l}\text { DSS-induced acute murine } \\
\text { colitis model }\end{array}$ & $\begin{array}{l}\text { Oral gavage astragalin at } 2 \\
\text { and } 5 \mathrm{mg} / \mathrm{kg}\end{array}$ & $\begin{array}{l}\text { Astragalin reduced the level of phosphorylated IkappaBalpha and decreased } \\
\text { the production of the inflammatory cytokines IL-6, IL-8, and TNF-alpha }\end{array}$ & (182) \\
\hline & $\begin{array}{l}\text { DSS-induced colitis male } \\
\text { C57BL/6 mice }\end{array}$ & $\begin{array}{l}\text { Daily oral doses of } 200 \mu \mathrm{L} \\
\text { of astragalin at } 50,75,100 \\
\mathrm{mg} / \mathrm{kg}\end{array}$ & $\begin{array}{l}\text { Astragalin might exert a good anti-UC effect through } \\
\text { microbiota/LPS/TLR4/NF-kB-related pathways in mice }\end{array}$ & (183) \\
\hline Quercetin & $\begin{array}{l}\text { Pathogen-free female C57BL/6 } \\
\text { mice infected by Citrobacter } \\
\text { rodentium }\end{array}$ & $\begin{array}{l}\text { Receiving a basal rodent } \\
\text { diet supplemented with } 30 \\
\text { mg/kg quercetin }\end{array}$ & $\begin{array}{l}\text { The Citrobacter rodentium-induced colitis mouse model proved quercetin } \\
\text { supplementation could enhance the populations of Bacteroides, } \\
\text { Bifidobacterium, Lactobacillus, Clostridia, and significantly reduced those of } \\
\text { Fusobacterium and Enterococcus }\end{array}$ & (184) \\
\hline
\end{tabular}

\section{FLAVONOIDS AND IBD}

Inflammatory bowel disease is characterized by the chronic inflammation of gastrointestinal tract. The development of disease course seriously impairs the quality of life of the patients, who then require sustained drug treatments and surgical interventions. Based on these situations, the treatment targets of IBD is the remission of symptoms during the acute flare and lowering the chronic inflammatory state (20). In order to overcome these problems, the effective and safe treatment strategies for the prevention and treatment of IBD are needed. Flavonoids may be one of such potential agents (Table 4). Previous studies have shown the following beneficial effects of flavonoids on the gastrointestinal tract: maintaining the integrity of the intestinal barrier; preventing the intestinal wall from pharmacological insults and food toxins; regulating the gut immune system; shaping the profiles of microbiota; regulating the gut hormonal secretions by enteroendocrine cells (Figure 4) (187).

\section{Flavonoids: Mucosal Integrity and the Function of Intestinal Epithelial Barrier}

The mucosal barrier is imperative for the maintenance of intestinal homeostasis. The dysfunction of intestinal barrier is correlated with the etiology of IBD (188). One of the prospective studies about the IBD patients and mucosal healing demonstrated the relationship between impaired intestinal permeability and ongoing bowel symptoms of diarrhea or abdominal pain (189). The in vivo DSS-induced mouse colitis models also demonstrated that the increase in the gut permeability resulted in chronic inflammatory responses (190, 191). The two main factors used for the evaluation of the function of intestinal mucosal barrier include the integrity of mucus layer and the production and assembly of tight junction proteins 


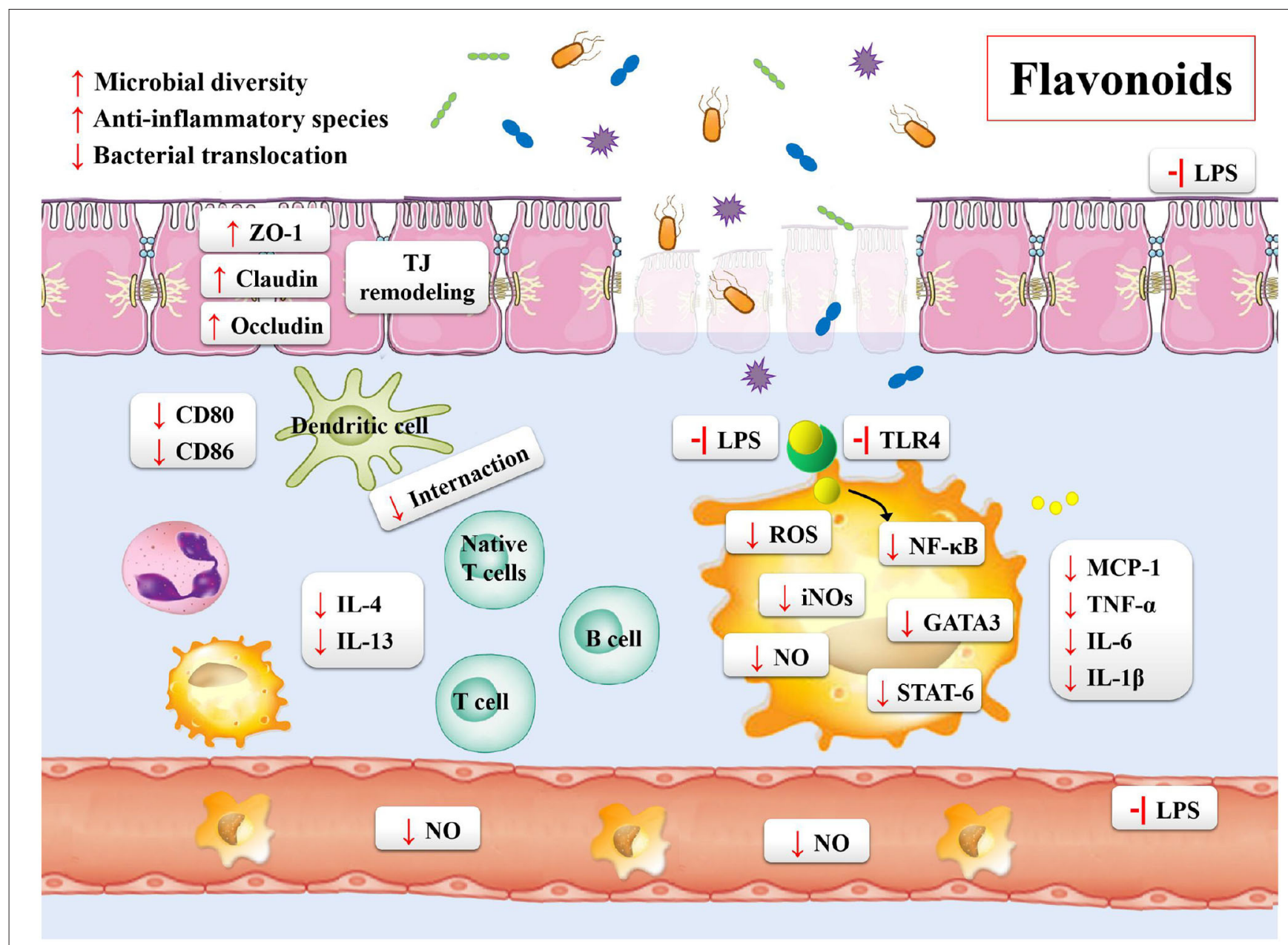

FIGURE 4 | The potential mechanisms of flavonoids on gut microbiota and IBD.

(192). The mucus layer provides a physicochemical barrier to protect the surface of epithelial cells. The tight junction proteins are the main determinants of intestinal physical barrier. The expression and association of the tight junction proteins and actin cytoskeleton determine the permeability of tight junction proteins, which are dynamically regulated by various intracellular signaling molecules. Studies have reported that flavonoids could enhance the integrity of tight junction proteins, including ZO-2, occludins, and occluding. Quercetin, myricetin, and kaempferol could enhance tight junction protein expression and inhibit PKC $\delta$ in human Caco- 2 cells $(193,194)$. In addition, the DSSinduced mouse model has also demonstrated that the supplement of naringenin decreased the disease activity index and expression of inflammatory cytokine (IL-6 and IL-17A) (175). In similar animal models, the sinensetin reversed the colitis-associated increase in the intestinal permeability, promoted the autophagy of epithelial cells, decreased the apoptosis of epithelial cells, and reduced the mucosal claudin-2 (176).

Many studies currently focus on the association of morphological and functional changes in the vascular endothelium with $\operatorname{IBD}(177,195-197)$. The functional and structural changes in vascular endothelium lead to the activation of endothelial cells. These changes cause the expression of a variety of cell-adhesion molecules and chemokines on the endothelia cell surface, including ICAM-1, VCAM-1, and IL-1 $\beta$, and the enrichment of leukocyte activation following inflammatory responses. As compared to healthy controls, the IBD patients showed an increase in the adhesion of CAM and leukocyte (195). Microvascular expression of CAMs could mediate the recruitment of circulating leukocytes. The quercetin has been reported to reduce the overproduction of TNF- $\alpha$, IL- $1 \beta$, interleukin-6, ICAM-1, and VCAM-1 in the cellular model of lipopolysaccharide (LPS)-induced rat intestinal microvascular endothelial cells (196). Using the same in vitro models, investigating the integrity of intestinal endothelial barrier, the naringin effectively ameliorated the disruption of gut-vascular barrier (197). The kaempferol showed similar effects. Moreover, it has a protective effect against the dysfunction of barrier via preventing the activation of NF- $\kappa \mathrm{B}$ signaling pathway in the LPS-induced epithelial-endothelial co-culture model (177). 


\section{Flavonoids and Immunomodulation}

The different activities and properties of flavonoids have important implications in the activation, maturation and signal transduction of cells and the production and secretion of several cytokines in immune cells (198). A recent study showed that the astragalin reduced the level of pro-inflammatory cytokines and their mRNAs, such as TNF- $\alpha$, IL- 6 , and IL-1 $\beta$, and affected the key relative groups abundance of potentially beneficial Ruminococcaceae and potentially harmful EscherichiaShigella (183). As mentioned previously, the imbalance of the immune system is associated with the pathogenesis of IBD. The adaptive immune system is usually considered as a main contributor to the pathogenesis of IBD, which may arise from an increase in the pro-inflammatory factors driven by $\mathrm{TH}$ cells and ineffectual anti-inflammatory $\mathrm{T}_{\text {reg }}$ cells (199). For example, using the DSS-induced mouse colitis models, Tao et al. found that the natural icariin inhibited the $\mathrm{T}_{\mathrm{H} 1} / \mathrm{T}_{\mathrm{H} 17}$ responses by suppressing the activation of STAT1 and STAT3, leading to the mitigation of inflammation (200). Abron et al. demonstrated that the genistein skewed the M1 macrophages toward M2 phenotypes, and reduced the systemic cytokine levels in part to attenuate the colitis symptoms (201). The majority of published studies performed using the experimental models of colitis have indicated that the altered immune response was correlated with the increasing release of pro-inflammatory cytokines, including IFN $\gamma, \mathrm{TNF} \alpha$, IL-6, IL-1 $\beta$, GM-CSF, and IL17A (20). With the increase in the mucosal permeability, the Toll-like receptors (TLRs) in endothelial cells of the intestinal epithelium are activated by the LPS exposed on the surface of gram-negative bacteria. In such case, the quercetin was found to prevent activation of inflammatory responses by inhibiting the LPS-induced expression of TLR4 in endothelium, through the MyD88-dependent NF- $\kappa$ B, MAPKs, and STAT pathways (202). In the 2,4,6-trinitrobenzenesulfonic acid (TNBS)-induced colitis mouse models, the baicalin exhibited anti-inflammatory effects by inhibiting the activation of TLR4/NF- $\mathrm{B}$ and PI3K/AKT pathways $(180,203)$. Likewise, the same in vivo models showed the beneficial effect of oral tangeretin, alleviating the disease symptoms in TNBS-induced colitis models. The possible mechanisms of action of tangeretin might be the inhibition of LPS binding to the immune cells, such as dendritic cells, by suppressing the expression of IL-12 and TNF- $\alpha$ as well as the activation of NF-кB (204). The similar results were also observed for astragalin and taxifolin $(182,205)$.

\section{Flavonoids and Gut Microbiota}

The interaction between flavonoids and microbiota offers considerable potential for the maintenance of gastrointestinal and systemic health. The beneficial effects of flavonoids for improving the health are not only attributed to their direct impact on the colon, but also to their alteration of the intestinal microbiota and performance of metabolism, which provide a therapeutic basis for the IBD with dysbiosis (187). Many studies have reported that the commonly observed variations in the IBD samples mainly focused on the reduced diversity of gut microbiota with reduction in the relative abundance of reducing Firmicutes and increasing Proteobacteria (206).
Flavonoids are reported to positively regulate the composition of gut microbiota. Several studies have shown a great therapeutic potential of the quercetin for the IBD patients, suppressing the abnormal expression of proinflammatory cytokines and modifying the gut microbiota by increasing the relative abundance of Bacteroides, Bifidobacterium, Lactobacillus, and Clostridia, while reducing the relative abundance of Fusobacterium and Enterococcus $(184,185)$. In addition, both the quercetin aglycone alone and in combination with the monoglycosides exhibited higher Chaol and Shannon indices and a lower Simpson index to counteract the adverse effect by colitis (207). Furthermore, the flavonoids upregulated the beneficial bacteria and down-regulated the growth of pathogen. Recently, the A. muciniphila showed protective effects against colitis in the DSS-induced colitis mouse models (208), confirming its main biological functions, which included the maintenance of gut barrier function and host metabolism $(168,209)$. Dietary supplementations with some flavonoids positively regulates this bacterial growth $(79,210,211)$. For example, cranberry extract treatment markedly increased the proportion of A. muciniphila, and it was identified that the daily intake of flavonols were at $18.8 \mathrm{mg} \mathrm{kg}^{-1} \mathrm{~d}^{-1}$, total anthocyanins were at $6.6 \mathrm{mg} \mathrm{kg}^{-1} \mathrm{~d}^{-1}$ (79). The Clostridium difficile infection (CDI) has dramatically increased over the past decade worldwide (212). This bacterium induces aberrant inflammatory immune responses, which causes the breakdown of gastrointestinal barrier in the genetically susceptible individuals, leading to the development of IBD (213). The literature evidence suggests that the flavonoids significantly reduce toxin synthesis, sporulation, and spore outgrowth of $C$. difficile, while down-regulates the genes critical for pathogenesis $(214,215)$.

The colonic inflammation stimulates the production of IFN$\gamma$, generating ROS by phagocytic innate immune cells, which causes a series of radicals as their end-products by facultative anaerobes. As a result, the bacterial diversity is decreased. Nevertheless, the beneficial effects of flavonoids for promoting the gut health are due to its anti-oxidant and free radicalscavenging activity (216). Most of the flavonoids assayed have the hallmark features of possessing numerous hydroxyl groups with the ability of amelioration oxidative stress $(20,216)$. A number of studies have reported that the flavonoids inhibit the expression of iNOS, while reduce the production of NO (20, 217). Moreover, the flavonoids enhance the activities of different enzymes having anti-oxidant properties, such as glutathione, superoxide dismutase and gluthathione peroxidases $(218,219)$.

\section{CONCLUSIONS AND FUTURE PERSPECTIVES}

In this review, the flavonoids have been systematically summarized, providing evidences with a focus on the interactions between flavonoids and gut microbiota and their potential therapeutic effect, including their potential mechanisms of action, on IBD. However, it should be noted that there are still many problems need to be solved. Currently, some aspects of the pathogenesis of IBD are not completely 
understood. The gut microbiota has been widely recognized as a key factor for the intestinal homeostasis and has correlation with the pathogenesis of IBD (220). The current therapies for IBD are comprised of corticosteroids, immunosuppressants, anti-biotics, and biological agents. However, these therapies are neither curative nor cost-effective. Furthermore, these therapies do not target the microorganisms directly for the cause or contribution to inflammation (221). Thus, to develop more effective strategies for the treatment of IBD still remains a challenge. The flavonoids have received much attention for their biological properties, as well as their anti-oxidant and anti-inflammatory activities have been well-documented. Meanwhile, the flavonoids and their metabolites also affect the intestinal ecology by regulating the microbiota with bacteriostatic or bactericidal effects for the pathogenic and harmful bacteria, and prebiotic effects for the beneficial bacteria (222). On the other hand, due to the low bioavailability of flavonoids, $90 \%$ of them persists in the colon. The gut microbiota exhibits a great metabolic capacity of metabolizing the flavonoids via hydrolyzation, demethylation, de-hydroxylation, and de-carboxylation, resulting in smaller metabolites, which are absorbed across the intestinal mucosa to benefit human health. In summary, flavonoids have tremendous therapeutic potential for the treatment of IBD. However, most flavonoids have poor water solubility, so their clinical application is hindered. Future studies could

\section{REFERENCES}

1. Molodecky NA, Soon IS, Rabi DM, Ghali WA, Ferris M, Chernoff G, et al. Increasing incidence and prevalence of the inflammatory bowel diseases with time, based on systematic review. Gastroenterology. (2012) 142:4654. doi: 10.1053/j.gastro.2011.10.001

2. Kaplan GG. The global burden of IBD: from 2015 to 2025. Nat Rev Gastroenterol Hepatol. (2015) 12:720-7. doi: 10.1038/nrgastro. 2015.150

3. Lloyd-Price J, Arze C, Ananthakrishnan AN, Schirmer M, Avila-Pacheco J, Poon TW, et al. Multi-omics of the gut microbial ecosystem in inflammatory bowel diseases. Nature. (2019) 569:655-62. doi: 10.1038/s41586-019-1237-9

4. Ley RE, Peterson DA, Gordon JI. Ecological and evolutionary forces shaping microbial diversity in the human intestine. Cell. (2006) 124:83748. doi: 10.1016/j.cell.2006.02.017

5. Qin J, Li R, Raes J, Arumugam M, Burgdorf KS, Manichanh C, et al. A human gut microbial gene catalogue established by metagenomic sequencing. Nature. (2010) 464:59-65. doi: 10.1038/nature08821

6. Sender R, Fuchs S, Milo R. Are We really vastly outnumbered? Revisiting the ratio of bacterial to host cells in humans. Cell. (2016) 164:33740. doi: 10.1016/j.cell.2016.01.013

7. Schirmer M, Garner A, Vlamakis H, Xavier RJ. Microbial genes and pathways in inflammatory bowel disease. Nat Rev Microbiol. (2019) 17:497511. doi: 10.1038/s41579-019-0213-6

8. Singh AK, Cabral C, Kumar R, Ganguly R, Rana HK, Gupta A, et al. Beneficial effects of dietary polyphenols on gut microbiota and strategies to improve delivery efficiency. Nutrients. (2019) 11:221637. doi: 10.3390/nu11092216

9. Huttenhower C, Gevers D, Knight R, Abubucker S, Badger JH, Chinwalla AT, et al. Structure, function and diversity of the healthy human microbiome. Nature. (2012) 486:207-14. doi: 10.1038/nature 11234

10. Proctor LM, Creasy HH, Fettweis JM, Lloyd-Price J, Mahurkar A, Zhou W, et al. The integrative human microbiome project. Nature. (2019) 569:6418. doi: 10.1038/s41586-019-1238-8 focus on IBD treatment by targeting gut microbiota and studying flavonoid drug delivery methods, including proteins, peptides, monoclonal anti-bodies, nucleic acids, and living cells, etc. The potential molecular mechanisms or toxicological assessments of flavonoid regulation of intestinal microbiota have not been well-elucidated, nor have their actual efficacy in the treatment of human IBD been proven. Thus, further research should also pay attention to more animal or cellular models and even clinical data to evaluate the safety and efficacy of flavonoid monomer molecules targeting gut microbiota against IBD.

\section{AUTHOR CONTRIBUTIONS}

$\mathrm{HH}$ conceived and designed the review. LW was mainly responsible for writing articles. $\mathrm{MG}$ and $\mathrm{GK}$ revised the manuscript. All authors were responsible for reading and approving the manuscript.

\section{FUNDING}

The present study was supported by grants from National Key Research and Development Project (No. 2019YFA0905600), Science and Technology Program of Tianjin, China (No. 19YFSLQY00110).
11. Lozupone CA, Stombaugh JI, Gordon JI, Jansson JK, Knight R. Diversity, stability and resilience of the human gut microbiota. Nature. (2012) 489:22030. doi: 10.1038/nature11550

12. Zmora N, Suez J, Elinav E. You are what you eat: diet, health and the gut microbiota. Nat Rev Gastroenterol Hepatol. (2019) 16:3556. doi: 10.1038/s41575-018-0061-2

13. Del Rio D, Rodriguez-Mateos A, Spencer JPE, Tognolini M, Borges G, Crozier A. Dietary (poly)phenolics in human health: structures, bioavailability, and evidence of protective effects against chronic diseases. Antioxid Redox Signal. (2013) 18:1818-92. doi: 10.1089/ars.2012.4581

14. Lu M-F, Xiao Z-T, Zhang H-Y. Where do health benefits of flavonoids come from? Insights from flavonoid targets and their evolutionary history. Biochem Biophys Res Commun. (2013) 434:701-4. doi: 10.1016/j.bbrc.2013.04.035

15. Cirillo G, Curcio M, Vittorio O, Iemma F, Restuccia D, Spizzirri UG, et al. Polyphenol conjugates and human health: a perspective review. Crit Rev Food Sci Nutr. (2016) 56:326-37. doi: 10.1080/10408398.2012.752342

16. Cao H, Ou JY, Chen L, Zhang YB, Szkudelski T, Delmas D, et al. Dietary polyphenols and type 2 diabetes: human study and clinical trial. Crit Rev Food Sci Nutr. (2019) 59:3371-9. doi: 10.1080/10408398.2018.1492900

17. Carlos Espin J, Gonzalez-Sarrias A, Tomas-Barberan FA. The gut microbiota: a key factor in the therapeutic effects of (poly) phenols. Biochem Pharmacol. (2017) 139:82-93. doi: 10.1016/j.bcp.2017.04.033

18. Loo YT, Howell K, Chan M, Zhang PZ, Ng K. Modulation of the human gut microbiota by phenolics and phenolic fiber-rich foods. Compr Rev Food Sci Food Saf. (2020) 19:1268-98. doi: 10.1111/1541-4337.12563

19. Peng MF, Tabashsum Z, Anderson M, Truong A, Houser AK, Padilla J, et al. Effectiveness of probiotics, prebiotics, and prebiotic-like components in common functional foods. Compr Rev Food Sci Food Saf. (2020) 19:190833. doi: 10.1111/1541-4337.12565

20. Vezza T, Rodriguez-Nogales A, Algieri F, Utrilla MP, Rodriguez-Cabezas ME, Galvez J. Flavonoids in inflammatory bowel disease: a review. Nutrients. (2016) 8:211-33. doi: 10.3390/nu8040211

21. Septembre-Malaterre A, Remize F, Poucheret P. Fruits and vegetables, as a source of nutritional compounds and phytochemicals: changes in 
bioactive compounds during lactic fermentation. Food Res Int. (2018) 104:86-99. doi: 10.1016/j.foodres.2017.09.031

22. Shabbir MA, Mehak F, Khan ZM, Ahmad W, Khan MR, Zia S, et al. Interplay between ceramides and phytonutrients: new insights in metabolic syndrome. Trends Food Sci Technol. (2021) 111:483-94. doi: 10.1016/j.tifs.2021.03.010

23. Martin C, Zhang Y, Tonelli C, Petroni K. Plants, diet, and health. Annu Rev Plant Biol. (2013) 64:19-46. doi: 10.1146/annurev-arplant-050312-120142

24. Martin C. A role for plant science in underpinning the objective of global nutritional security? Ann Bot. (2018) 122:541-53. doi: 10.1093/aob/mcyl18

25. Wlodarska M, Willing BP, Bravo DM, Finlay BB. Phytonutrient diet supplementation promotes beneficial Clostridia species and intestinal mucus secretion resulting in protection against enteric infection. Sci Rep. (2015) 5:1-9. doi: 10.1038/srep09253

26. Putta S, Yarla NS, Kumar EK, Lakkappa DB, Kamal MA, Scotti $\mathrm{L}$, et al. Preventive and therapeutic potentials of anthocyanins in diabetes and associated complications. Curr Med Chem. (2018) 25:534771. doi: 10.2174/0929867325666171206101945

27. Ogunleye AA, Xue F, Michels KB. Green tea consumption and breast cancer risk or recurrence: a meta-analysis. Breast Cancer Res Treat. (2010) 119:47784. doi: 10.1007/s10549-009-0415-0

28. Jeong WY, Jin JS, Cho YA, Lee JH, Park S, Jeong SW, et al. Determination of polyphenols in three Capsicum annuum L. (bell pepper) varieties using high-performance liquid chromatography-tandem mass spectrometry: their contribution to overall antioxidant and anticancer activity. J Separ Sci. (2011) 34:2967-74. doi: 10.1002/jssc.201100524

29. Mulvihill EE, Huff MW. Antiatherogenic properties of flavonoids: implications for cardiovascular health. Can J Cardiol. (2010) 26:17A-21A. doi: 10.1016/s0828-282x(10)71056-4

30. Zakaria ZA, Hisam EEA, Rofiee MS, Norhafizah M, Somchit MN, Teh LK, et al. In vivo antiulcer activity of the aqueous extract of Bauhinia purpurea leaf. J Ethnopharmacol. (2011) 137:1047-54. doi: 10.1016/j.jep.2011.07.038

31. Han N, Gu Y, Ye C, Cao Y, Liu Z, Yin J. Antithrombotic activity of fractions and components obtained from raspberry leaves (Rubus chingii). Food Chem. (2012) 132:181-5. doi: 10.1016/j.foodchem.2011.10.051

32. Tao W-W, Duan J-A, Yang N-Y, Tang Y-P, Liu M-Z, Qian YF. Antithrombotic phenolic compounds from Glycyrrhiza uralensis. Fitoterapia. (2012) 83:422-5. doi: 10.1016/j.fitote.2011.12.010

33. Beara IN, Lesjak MM, Orcic DZ, Simin ND, Cetojevic-Simin DD, Bozin $\mathrm{BN}$, et al. Comparative analysis of phenolic profile, antioxidant, antiinflammatory and cytotoxic activity of two closely-related Plantain species: Plantago altissima L. and Plantago lanceolata L. LWT Food Sci Technol. (2012) 47:64-70. doi: 10.1016/j.lwt.2012.01.001

34. Zimmer AR, Leonardi B, Miron D, Schapoval E, de Oliveira JR, Gosmann G. Antioxidant and anti-inflammatory properties of Capsicum baccatum: from traditional use to scientific approach. J Ethnopharmacol. (2012) 139:22833. doi: $10.1016 /$ j.jep.2011.11.005

35. Schmitz-Eiberger MA, Blanke MM. Bioactive components in forced sweet cherry fruit (Prunus avium L), antioxidative capacity and allergenic potential as dependent on cultivation under cover. LWT Food Sci Technol. (2012) 46:388-92. doi: 10.1016/j.lwt.2011.12.015

36. Schuetz K, Sass M, de With A, Graubaum H-J, Gruenwald J. Immunemodulating efficacy of a polyphenol-rich beverage on symptoms associated with the common cold: a double-blind, randomised, placebo-controlled, multi-centric clinical study. Br J Nutr. (2010) 104:1156-64. doi: 10.1017/s0007114510002047

37. Bijak M, Bobrowski M, Borowiecka M, Podsedek A, Golanski J, Nowak P. Anticoagulant effect of polyphenols-rich extracts from black chokeberry and grape seeds. Fitoterapia. (2011) 82:811-7. doi: 10.1016/j.fitote.2011.04.017

38. Xia D, Wu X, Shi J, Yang Q, Zhang Y. Phenolic compounds from the edible seeds extract of Chinese Mei (Prunus mume Sieb. et Zucc) and their antimicrobial activity. LWT Food Sci Technol. (2011) 44:3479. doi: 10.1016/j.lwt.2010.05.017

39. Silva JC, Rodrigues S, Feas X, Estevinho LM. Antimicrobial activity, phenolic profile and role in the inflammation of propolis. Food Chem Toxicol. (2012) 50:1790-5. doi: 10.1016/j.fct.2012.02.097

40. Ji XW, Wu B, Zhou ZQ, Kang DG, Lee HS, Cho KW, et al. Mechanisms of vasodilatory effects of total flavonoids from Euphorbia humifusa in rat aorta. Faseb J. (2017) 31:619-28. doi: 10.1096/fasebj.31.1_supplement.835.13
41. Wan Y, Yu Y, Pan X, Mo X, Gong W, Liu X, et al. Inhibition on acid-sensing ion channels and analgesic activities of flavonoids isolated from dragon's blood resin. Phytother Res. (2019) 33:718-27. doi: 10.1002/ptr.6262

42. Rodriguez-Mateos A, Vauzour D, Krueger CG, Shanmuganayagam D, Reed J, Calani L, et al. Bioavailability, bioactivity and impact on health of dietary flavonoids and related compounds: an update. Arch Toxicol. (2014) 88:180353. doi: 10.1007/s00204-014-1330-7

43. Farhadi F, Khameneh B, Iranshahi M, Iranshahy M. Antibacterial activity of flavonoids and their structure-activity relationship: an update review. Phytother Res. (2019) 33:13-40. doi: 10.1002/ptr.6208

44. Gowd V, Karim N, Shishir MRI, Xie L, Chen W. Dietary polyphenols to combat the metabolic diseases via altering gut microbiota. Trends Food Sci Technol. (2019) 93:81-93. doi: 10.1016/j.tifs.2019.09.005

45. Rendeiro C, Spencer JPE, Vauzour D, Butler LT, Ellis JA, Williams CM. The impact of flavonoids on spatial memory in rodents: from behaviour to underlying hippocampal mechanisms. Genes Nutr. (2009) 4:251-70. doi: 10.1007/s12263-009-0137-2

46. Kesse-Guyot E, Fezeu L, Andreeva VA, Touvier M, Scalbert A, Hercberg $\mathrm{S}$, et al. Total and specific polyphenol intakes in midlife are associated with cognitive function measured 13 years later. J Nutr. (2012) 142:7683. doi: $10.3945 /$ jn. 111.144428

47. Neshatdoust S, Saunders C, Castle SM, Vauzour D, Williams C, Butler L, et al. High-flavonoid intake induces cognitive improvements linked to changes in serum brain-derived neurotrophic factor: two randomised, controlled trials. Nutr Health Aging. (2016) 4:81-93. doi: 10.3233/nha-1615

48. Koebe T, Witte AV, Schnelle A, Tesky VA, Pantel J, Schuchardt J-P, et al. Impact of resveratrol on glucose control, hippocampal structure and connectivity, and memory performance in patients with mild cognitive impairment. Front Neurosci. (2017) 11:105. doi: 10.3389/fnins.2017. 00105

49. Holland TM, Agarwal P, Wang Y, Leurgans SE, Bennett DA, Booth SL, et al. Dietary flavonols and risk of Alzheimer dementia. Neurology. (2020) 94:e1749-56. doi: 10.1212/wnl.000000000 0008981

50. Hooper L, Kay C, Abdelhamid A, Kroon PA, Cohn JS, Rimm EB, et al. Effects of chocolate, cocoa, and flavan-3-ols on cardiovascular health: a systematic review and meta-analysis of randomized trials. Amer J Clin Nutr. (2012) 95:740-51. doi: 10.3945/ajen.111.023457

51. Peterson JJ, Dwyer JT, Jacques PF, McCullough ML. Associations between flavonoids and cardiovascular disease incidence or mortality in European and US populations. Nutr Rev. (2012) 70:491-508. doi: 10.1111/j.1753-4887.2012.0 0508.x

52. Ried K, Sullivan TR, Fakler P, Frank OR, Stocks NP. Effect of cocoa on blood pressure. Cochrane Database Syst Rev. (2012) 8:CD008893. doi: 10.1002/14651858.CD008893.pub2

53. Wang X, Ouyang YY, Liu J, Zhao G. Flavonoid intake and risk of CVD: a systematic review and meta-analysis of prospective cohort studies. Br J Nutr. (2014) 111:1-11. doi: 10.1017/s000711451300278x

54. Di Lorenzo A, Curti V, Tenore GC, Nabavi SM, Daglia M. Effects of tea and coffee consumption on cardiovascular diseases and relative risk factors: an update. Curr Pharm Des. (2017) 23:2474-87. doi: 10.2174/1381612823666170215145855

55. Dzoyem JP, Hamamoto H, Ngameni B, Ngadjui BT, Sekimizu K. Antimicrobial action mechanism of flavonoids from Dorstenia species. Drug Discov Ther. (2013) 7:66-72. doi: 10.5582/ddt.2013.v7.2.66

56. Suriyanarayanan B, Shanmugam K, Santhosh RS. Synthetic quercetin inhibits mycobacterial growth possibly by interacting with DNA gyrase. Rom Biotechnol Lett. (2013) 18:8587-93.

57. Roy R, Tiwari M, Donelli G, Tiwari V. Strategies for combating bacterial biofilms: a focus on anti-biofilm agents and their mechanisms of action. Virulence. (2018) 9:522-54. doi: 10.1080/21505594.2017.1313372

58. Gorniak I, Bartoszewski R, Kroliczewski J. Comprehensive review of antimicrobial activities of plant flavonoids. Phytochem Rev. (2019) 18:24172. doi: 10.1007/s11101-018-9591-z

59. Lee KW, Bode AM, Dong Z. Molecular targets of phytochemicals for cancer prevention. Nat Rev Cancer. (2011) 11:211-8. doi: 10.1038/nrc 3017 
60. Albini A, Tosetti F, Li VW, Noonan DM, Li WW. Cancer prevention by targeting angiogenesis. Nat Rev Clin Oncol. (2012) 9:498-509. doi: 10.1038/nrclinonc.2012.120

61. Chen L, Teng H, Jia Z, Battino M, Miron A, Yu Z, et al. Intracellular signaling pathways of inflammation modulated by dietary flavonoids: the most recent evidence. Crit Rev Food Sci Nutr. (2018) 58:290824. doi: 10.1080/10408398.2017.1345853

62. Ozdal T, Sela DA, Xiao J, Boyacioglu D, Chen F, Capanoglu E. The reciprocal interactions between polyphenols and gut microbiota and effects on bioaccessibility. Nutrients. (2016) 8:78. doi: 10.3390/nu8020078

63. Zhao CY, Wang F, Lian YH, Xiao H, Zheng JK. Biosynthesis of citrus flavonoids and their health effects. Crit Rev Food Sci Nutr. (2020) 60:56683. doi: 10.1080/10408398.2018.1544885

64. Xiao J, Capanoglu E, Jassbi AR, Miron A. Advance on the flavonoid Cglycosides and health benefits. Crit Rev Food Sci Nutr. (2016) 56:S2945. doi: 10.1080/10408398.2015.1067595

65. Xiao J. Dietary flavonoid aglycones and their glycosides: which show better biological significance? Crit Rev Food Sci Nutr. (2017) 57:1874905. doi: 10.1080/10408398.2015.1032400

66. Stevens Y, Van Rymenant E, Grootaert C, Van Camp J, Possemiers S, Masclee A, et al. The intestinal fate of citrus flavanones and their effects on gastrointestinal health. Nutrients. (2019) 11:1464. doi: 10.3390/nu11071464

67. Cao H, Chen X, Jassbi AR, Xiao J. Microbial biotransformation of bioactive flavonoids. Biotechnol Adv. (2015) 33:21423. doi: 10.1016/j.biotechadv.2014.10.012

68. Plaza M, Pozzo T, Liu J, Ara KZG, Turner C, Karlsson EN. Substituent effects on in vitro antioxidizing properties, stability, and solubility in flavonoids. $J$ Agric Food Chem. (2014) 62:3321-33. doi: 10.1021/jf405570u

69. Park H, Jin U-H, Orr AA, Echegaray SP, Davidson LA, Allred $\mathrm{CD}$, et al. Isoflavones as $\mathrm{Ah}$ receptor agonists in colon-derived cell lines: structure-activity relationships. Chem Res Toxicol. (2019) 32:2353-64. doi: 10.1021/acs.chemrestox.9b00352

70. Jung YS, Rha C-S, Baik M-Y, Baek N-I, Kim D-O. A brief history and spectroscopic analysis of soy isoflavones. Food Sci Biotechnol. (2020). 29:1605-17. doi: 10.1007/s10068-020-00815-6

71. Krizova L, Dadakova K, Kasparovska J, Kasparovsky T. Isoflavones. Molecules. (2019) 24:1076. doi: 10.3390/molecules24061076

72. Rodriguez-Amaya DB. Update on natural food pigments - a mini-review on carotenoids, anthocyanins, and betalains. Food Res Int. (2019) 124:2005. doi: 10.1016/j.foodres.2018.05.028

73. Fang J. Bioavailability of anthocyanins. Drug Metab Rev. (2014) 46:50820. doi: 10.3109/03602532.2014.978080

74. Pinent M, Blay M, Serrano J, Ardevol A. Effects of flavanols on the enteroendocrine system: repercussions on food intake. Crit Rev Food Sci Nutr. (2017) 57:326-34. doi: 10.1080/10408398.2013.871221

75. Moco S, Martin F-PJ, Rezzi S. Metabolomics view on gut microbiome modulation by polyphenol-rich foods. J Proteome Res. (2012) 11:478190. doi: 10.1021/pr300581s

76. Valdes L, Cuervo A, Salazar N, Ruas-Madiedo P, Gueimonde M, Gonzalez S. The relationship between phenolic compounds from diet and microbiota: impact on human health. Food Funct. (2015) 6:242439. doi: 10.1039/c5fo00322a

77. Mayta-Apaza AC, Pottgen E, De Bodt J, Papp N, Marasini D, Howard L, et al. Impact of tart cherries polyphenols on the human gut microbiota and phenolic metabolites in vitro and in vivo. J Nutr Biochem. (2018) 59:160-72. doi: 10.1016/j.jnutbio.2018.04.001

78. Rha C-S, Seong H, Jung YS, Jang D, Kwak J-G, Kim D-O, et al. Stability and fermentability of green tea flavonols in in-vitro-simulated gastrointestinal digestion and human fecal fermentation. Int J Mol Sci. (2019) 20:5890. doi: 10.3390/ijms20235890

79. Anhe FF, Roy D, Pilon G, Dudonne S, Matamoros S, Varin TV, et al. A polyphenol-rich cranberry extract protects from diet-induced obesity, insulin resistance and intestinal inflammation in association with increased Akkermansia spp. population in the gut microbiota of mice. Gut. (2015) 64:872-83. doi: 10.1136/gutjnl-2014-307142

80. Huang JC, Chen L, Xue B, Liu QY, Ou SY, Wang Y, et al. Different flavonoids can shape unique gut microbiota profile in vitro. J Food Sci. (2016) 81:H2273-9. doi: 10.1111/1750-3841.13411
81. Kawabata K, Sugiyama Y, Sakano T, Ohigashi H. Flavonols enhanced production of anti-inflammatory substance(s) by Bifidobacterium adolescentis: prebiotic actions of galangin, quercetin, and fisetin. Biofactors. (2013) 39:422-9. doi: 10.1002/biof.1081

82. Parkar SG, Stevenson DE, Skinner MA. The potential influence of fruit polyphenols on colonic microflora and human gut health. Int $J$ Food Microbiol. (2008) 124:295-8. doi: 10.1016/j.ijfoodmicro.2008.03.017

83. Yeon MJ, Lee MH, Kim DH, Yang JY, Woo HJ, Kwon HJ, et al. Anti-inflammatory effects of Kaempferol on Helicobacter pylori-induced inflammation. Biosci Biotechnol Biochem. (2019) 83:166-73. doi: 10.1080/09168451.2018.1528140

84. Chen M-E, Su C-H, Yang J-S, Lu C-C, Hou Y-C, Wu J-B, et al. Baicalin, Baicalein, and Lactobacillus rhamnosus JB3 alleviated Helicobacter pylori infections in vitro and in vivo. J Food Sci. (2018) 83:311825. doi: 10.1111/1750-3841.14372

85. Eteberria U, Arias N, Boque N, Macarulla MT, Portillo MP, Martinez JA, et al. Reshaping faecal gut microbiota composition by the intake of transresveratrol and quercetin in high-fat sucrose diet-fed rats. J Nutr Biochem. (2015) 26:651-60. doi: 10.1016/j.jnutbio.2015.01.002

86. Nie J, Zhang L, Zhao G, Du X. Quercetin reduces atherosclerotic lesions by altering the gut microbiota and reducing atherogenic lipid metabolites. J Appl Microbiol. (2019) 127:1824-34. doi: 10.1111/jam.14441

87. Porras D, Nistal E, Martinez-Florez S, Luis Olcoz J, Jover R, Jorquera F, et al. Functional interactions between gut microbiota transplantation, quercetin, and high-fat diet determine non-alcoholic fatty liver disease development in germ-free mice. Mol Nutr Food Res. (2019). 63:e1800930. doi: 10.1002/mnfr.201800930

88. Zhang BW, Sun WL, Yu N, Sun J, Yu XX, Li X, et al. Anti-diabetic effect of baicalein is associated with the modulation of gut microbiota in streptozotocin and high-fat-diet induced diabetic rats. J Funct Foods. (2018) 46:256-67. doi: 10.1016/j.jff.2018.04.070

89. Lopez P, Sanchez M, Perez-Cruz C, Velazquez-Villegas LA, Syeda T, Aguilar-Lopez $\mathrm{M}$, et al. Long-term genistein consumption modifies gut microbiota, improving glucose metabolism, metabolic endotoxemia, and cognitive function in mice fed a high-fat diet. Mol Nutr Food Res. (2018) 62:e1800313. doi: 10.1002/mnfr.201800313

90. Lv M, Yang S, Cai L, Qin L-q, Li B-y, Wan Z. Effects of quercetin intervention on cognition function in APP/PS1 mice was affected by vitamin D status. Mol Nutr Food Res. (2018) 62 :e1800621. doi: 10.1002/mnfr. 201800621

91. Huang G, Xu J, Cai D, Chen S-Y, Nagy T, Guo TL. Exacerbation of type 1 diabetes in perinatally genistein exposed female non-obese diabetic (NOD) mouse is associated with alterations of gut microbiota and immune homeostasis. Toxicol Sci. (2018) 165:291-301. doi: 10.1093/toxsci/kfy162

92. Truchado P, Gimenez-Bastida J-A, Larrosa M, Castro-Ibanez I, Carlos Espin J, Tomas-Barberan FA, et al. Inhibition of quorum sensing (QS) in Yersinia enterocolitica by an orange extract rich in glycosylated flavanones. J Agric Food Chem. (2012) 60:8885-94. doi: 10.1021/jf301365a

93. Bustos I, Garcia-Cayuela T, Hernandez-Ledesma B, Pelaez C, Requena T, Carmen Martinez-Cuesta M. Effect of flavan-3-ols on the adhesion of potential probiotic Lactobacilli to intestinal cells. J Agric Food Chem. (2012) 60:9082-8. doi: 10.1021/jf301133g

94. Cueva C, Sanchez-Patan F, Monagas M, Walton GE, Gibson GR, Martin-Alvarez PJ, et al. In vitro fermentation of grape seed flavan3-ol fractions by human faecal microbiota: changes in microbial groups and phenolic metabolites. FEMS Microbiol Ecol. (2013) 83:792-805. doi: 10.1111/1574-6941.12037

95. Cardona F, Andres-Lacueva C, Tulipani S, Tinahones FJ, Isabel Queipo-Ortuno M. Benefits of polyphenols on gut microbiota and implications in human health. J Nutr Biochem. (2013) 24:1415-22. doi: 10.1016/j.jnutbio.2013.05.001

96. Ouyang J, Sun F, Feng W, Sun Y, Qiu X, Xiong L, et al. Quercetin is an effective inhibitor of quorum sensing, biofilm formation and virulence factors in Pseudomonas aeruginosa. J Appl Microbiol. (2016) 120:96674. doi: 10.1111/jam.13073

97. Lee JH, Park JH, Cho HS, Joo SW, Cho MH, Lee J. Anti-biofilm activities of quercetin and tannic acid against Staphylococcus aureus. Biofouling. (2013) 29:491-9. doi: 10.1080/08927014.2013.788692 
98. Aa L-x, Fei F, Qi Q, Sun R-b, Gu S-h, Di Z-z, et al. Rebalancing of the gut flora and microbial metabolism is responsible for the anti-arthritis effect of kaempferol. Acta Pharmacol Sin. (2020) 41:7381. doi: 10.1038/s41401-019-0279-8

99. Wu T, Zang X, He M, Pan S, Xu X. Structure-activity relationship of flavonoids on their anti-Escherichia coli activity and inhibition of DNA gyrase. J Agric Food Chem. (2013) 61:8185-90. doi: 10.1021/jf402222v

100. Taheri Y, Suleria HAR, Martins N, Sytar O, Beyatli A, Yeskaliyeva $\mathrm{B}$, et al. Myricetin bioactive effects: moving from preclinical evidence to potential clinical applications. BMC Complement Med Ther. (2020) 20:14. doi: 10.1186/s12906-020-03033-Z

101. Silva LN, Da Hora GCA, Soares TA, Bojer MS, Ingmer H, Macedo AJ, et al. Myricetin protects Galleria mellonella against Staphylococcus aureus infection and inhibits multiple virulence factors. Sci Rep. (2017) 7:16. doi: 10.1038/s41598-017-02712-1

102. Wang M, Firrman J, Liu L, Yam K. A Review on flavonoid apigenin: dietary intake, ADME, antimicrobial effects, and interactions with human gut microbiota. Biomed Res Int. (2019) 2019:1-19. doi: 10.1155/2019/7010467

103. Wang MQ, Firrman J, Zhang LQ, Arango-Argoty G, Tomasula P, Liu LS, et al. Apigenin impacts the growth of the gut microbiota and alters the gene expression of Enterococcus. Molecules. (2017) 22:22. doi: 10.3390/molecules22081292

104. Gao L, Li J, Zhou Y, Huang X, Qin X, Du G. Effects of baicalein on cortical proinflammatory cytokines and the intestinal microbiome in senescence accelerated mouse prone 8. ACS Chem Neurosci. (2018) 9:171424. doi: 10.1021/acschemneuro.8b00074

105. Andrade N, Marques C, Andrade S, Silva C, Rodrigues I, Guardao $\mathrm{L}$, et al. Effect of chrysin on changes in intestinal environment and microbiome induced by fructose-feeding in rats. Food Funct. (2019) 10:456676. doi: 10.1039/c9fo01142k

106. Paul B, Royston KJ, Li Y, Stoll ML, Skibola CF, Wilson LS, et al. Impact of genistein on the gut microbiome of humanized mice and its role in breast tumor inhibition. PLoS ONE. (2017) 12 :e0189756. doi: 10.1371/journal.pone.0189756

107. Reygaert WC. The antimicrobial possibilities of green tea. Front Microbiol. (2014) 5:434. doi: 10.3389/fmicb.2014.00434

108. Reza MA, Hossain MA, Lee S-J, Kim J-C, Park S-C. In vitro prebiotic effects and quantitative analysis of Bulnesia sarmienti extract. J Food Drug Anal. (2016) 24:822-30. doi: 10.1016/j.jfda.2016.03.015

109. Li L, Somerset S. Associations between flavonoid intakes and gut microbiota in a group of adults with cystic fibrosis. Nutrients. (2018) 10:1264. doi: 10.3390/nu10091264

110. Firrman J, Liu L, Argoty GA, Zhang L, Tomasula P, Wang M, et al. Analysis of temporal changes in growth and gene expression for commensal gut microbes in response to the polyphenol naringenin. Microbiol Insights. (2018) 11:1-12. doi: 10.1177/1178636118775100

111. Vikram A, Jayaprakasha GK, Jesudhasan PR, Pillai SD, Patil BS. Suppression of bacterial cell-cell signalling, biofilm formation and type III secretion system by citrus flavonoids. J Appl Microbiol. (2010) 109:51527. doi: 10.1111/j.1365-2672.2010.04677.x

112. He XW, Ouyang P, Yuan ZW, Yin ZQ, Fu HL, Lin JC, et al. Eriodictyol protects against Staphylococcus aureus-induced lung cell injury by inhibiting alpha-hemolysin expression. World J Microbiol Biotechnol. (2018) 34:7. doi: 10.1007/s11274-018-2446-3

113. Liu F, Wang TTY, Tang Q, Xue C, Li RW, Wu VCH. Malvidin 3-glucoside modulated gut microbial dysbiosis and global metabolome disrupted in a murine colitis model induced by dextran sulfate sodium. Mol Nutr Food Res. (2019) 63:e1900455. doi: 10.1002/mnfr.201900455

114. Hidalgo M, Oruna-Concha MJ, Kolida S, Walton GE, Kallithraka S, Spencer JPE, et al. Metabolism of anthocyanins by human gut microflora and their influence on gut bacterial growth. J Agric Food Chem. (2012) 60:388290. doi: 10.1021/jf3002153

115. Chen G, Wang G, Zhu C, Jiang X, Sun J, Tian L, et al. Effects of cyanidin-3-O-glucoside on 3-chloro-1,2-propanediol induced intestinal microbiota dysbiosis in rats. Food Chem Toxicol. (2019) 133:110767. doi: 10.1016/j.fct.2019.110767

116. Gonzales GB, Smagghe G, Grootaert C, Zotti M, Raes K, Van Camp J. Flavonoid interactions during digestion, absorption, distribution and metabolism: a sequential structure-activity/property relationship-based approach in the study of bioavailability and bioactivity. Drug Metab Rev. (2015) 47:175-90. doi: 10.3109/03602532.2014.1003649

117. Luca SV, Macovei I, Bujor A, Miron A, Skalicka-Wozniak K, Aprotosoaie AC, et al. Bioactivity of dietary polyphenols: the role of metabolites. Crit Rev Food Sci Nutr. (2020) 60:626-59. doi: 10.1080/10408398.2018.1546669

118. Marotti I, Bonetti A, Biavati B, Catizone P, Dinelli, G. Biotransformation of common bean (Phaseolus vulgaris L.) flavonoid glycosides by Bifidobacterium species from human intestinal origin. J Agric Food Chem. (2007) 55:3913-9. doi: 10.1021/jf062997g

119. Avila M, Hidalgo M, Sanchez-Moreno C, Pelaez C, Requena T, de Pascual-Teresa S. Bioconversion of anthocyanin glycosides by Bifidobacteria and Lactobacillus. Food Research International. (2009) 42:1453-61. doi: 10.1016/j.foodres.2009.07.026

120. Raimondi S, Roncaglia L, De Lucia M, Amaretti A, Leonardi A, Pagnoni $\mathrm{UM}$, et al. Bioconversion of soy isoflavones daidzin and daidzein by Bifidobacterium strains. Appl Microbiol Biotechnol. (2009) 81:94350. doi: 10.1007/s00253-008-1719-4

121. Youn SY, Park MS, Ji GE. Identification of the $\beta$-glucosidase gene from Bifidobacterium animalis subsp lactis and its expression in B. bifidum BGN4. J Microbiol Biotechnol. (2012) 22:1714-23. doi: 10.4014/jmb.1208. 08028

122. Michlmayr H, Kneifel W. $\beta$-Glucosidase activities of lactic acid bacteria: mechanisms, impact on fermented food and human health. FEMS Microbiol Lett. (2014) 352:1-10. doi: 10.1111/1574-6968.12348

123. Delgado S, Guadamuro L, Belen Florez A, Vazquez L, Mayo B. Fermentation of commercial soy beverages with Lactobacilli and Bifidobacteria strains featuring high beta-glucosidase activity. Innov Food Sci Emerg Technol. (2019) 51:148-55. doi: 10.1016/j.ifset.2018.03.018

124. Gaya P, Peiroten A, Landete JM. Expression of a beta-glucosidase in bacteria with biotechnological interest confers them the ability to deglycosylate lignans and flavonoids in vegetal foods. Appl Microbiol Biotechnol. (2020) 4903-13. doi: 10.1007/s00253-020-10588-x

125. Yang J, Qian DW, Jiang S, Shang EX, Guo JM, Duan JA. Identification of rutin deglycosylated metabolites produced by human intestinal bacteria using UPLC-Q-TOF/MS. J Chromatogr B Anal Technol Biomed Life Sci. (2012) 898:95-100. doi: 10.1016/j.jchromb.2012.04.024

126. Amaretti A, Raimondi S, Leonardi A, Quartieri A, Rossi M. Hydrolysis of the rutinose-conjugates flavonoids rutin and hesperidin by the gut microbiota and Bifidobacteria. Nutrients. (2015) 7:2788-800. doi: 10.3390/nu7042788

127. Shin NR, Moon JS, Shin SY, Li L, Lee YB, Kim TJ, et al. Isolation and characterization of human intestinal Enterococcus avium EFEL009 converting rutin to quercetin. Lett Appl Microbiol. (2016) 62:68-74. doi: 10.1111/lam.12512

128. Tao J-h, Duan J- a, Jiang S, Qian Y-y, Qian D-w. Biotransformation and metabolic profile of buddleoside with human intestinal microflora by ultrahigh-performance liquid chromatography coupled to hybrid linear ion trap/orbitrap mass spectrometer. J Chromatogr B Anal Technol Biomed Life Sci. (2016) 1025:7-15. doi: 10.1016/j.jchromb.2016.04.055

129. Pereira-Caro G, Fernandez-Quiros B, Ludwig IA, Pradas I, Crozier A, Manuel Moreno-Rojas J. Catabolism of citrus flavanones by the probiotics Bifidobacterium longum and Lactobacillus rhamnosus. Eur J Nutr. (2018) 57:231-42. doi: 10.1007/s00394-016-1312-Z

130. Braune A, Blaut M. Bacterial species involved in the conversion of dietary flavonoids in the human gut. Gut Microbes. (2016) 7:21634. doi: 10.1080/19490976.2016.1158395

131. del Carmen Villegas-Aguilar M, Fernandez-Ochoa A, de la Luz Cadiz-Gurrea M, Pimentel-Moral S, Lozano-Sanchez J, Arraez-Roman D, et al. Pleiotropic biological effects of dietary phenolic compounds and their metabolites on energy metabolism, inflammation and aging. Molecules. (2020) 25:127. doi: 10.3390/molecules 25030596

132. Possemiers S, Heyerick A, Robbens V, De Keukeleire D, Verstraete W. Activation of proestrogens from hops (Humulus lupulus L.) by intestinal microbiota; Conversion of isoxanthohumol into 8-prenylnaringenin. J Agric Food Chem. (2005) 53:6281-8. doi: 10.1021/jf0509714

133. Kim M, Kim N, Han J. Metabolism of Kaempferia parviflora polymethoxyflavones by human intestinal bacterium Bautia sp MRG-PMF1. J Agric Food Chem. (2014) 62:12377-83. doi: 10.1021/jf504074n 
134. Burapan S, Kim M, Han J. Curcuminoid demethylation as an alternative metabolism by human intestinal microbiota. J Agric Food Chem. (2017) 65:3306-11. doi: 10.1021/acs.jafc.7b00943

135. Burapan S, Kim M, Han J. Demethylation of polymethoxyflavones by human gut bacterium, Blautia sp MRG-PMF1. J Agric Food Chem. (2017) 65:16209. doi: 10.1021/acs.jafc.7b00408

136. Feng $\mathrm{XC}, \mathrm{Li} \mathrm{Y}$, Oppong $\mathrm{MB}$, Qiu $\mathrm{F}$. Insights into the intestinal bacterial metabolism of flavonoids and the bioactivities of their microbederived ring cleavage metabolites. Drug Metab Rev. (2018) 50:34356. doi: 10.1080/03602532.2018.1485691

137. Braune A, Blaut M. Deglycosylation of puerarin and other aromatic C-glucosides by a newly isolated human intestinal bacterium. Environ Microbiol. (2011) 13:482-94. doi: 10.1111/j.1462-2920.2010.02352.x

138. Kutschera M, Engst W, Blaut M, Braune A. Isolation of catechinconverting human intestinal bacteria. J Appl Microbiol. (2011) 111:16575. doi: 10.1111/j.1365-2672.2011.05025.x

139. Schoefer L, Mohan R, Schwiertz A, Braune A, Blaut M. Anaerobic degradation of flavonoids by Clostridium orbiscindens. Appl Environ Microbiol. (2003) 69:5849-54. doi: 10.1128/aem.69.10.5849-5854.2003

140. Caruso R, Lo BC, Nunez G. Host-microbiota interactions in inflammatory bowel disease. Nat Rev Immunol. (2020) 20:411-26. doi: 10.1038/s41577-019-0268-7

141. Vilela de Oliveira GL, Leite AZ, Higuchi BS, Gonzaga MI, Mariano VS. Intestinal dysbiosis and probiotic applications in autoimmune diseases. Immunology. (2017) 152:1-12. doi: 10.1111/imm.12765

142. Dore J, Blottiere H. The influence of diet on the gut microbiota and its consequences for health. Curr Opin Biotechnol. (2015) 32:1959. doi: 10.1016/j.copbio.2015.01.002

143. Bokulich NA, Chung J, Battaglia T, Henderson N, Jay M, Li H, et al. Antibiotics, birth mode, and diet shape microbiome maturation during early life. Sci Transl Med. (2016) 8:1-14. doi: 10.1126/scitranslmed.aad7121

144. Sonnenburg JL, Backhed F. Diet-microbiota interactions as moderators of human metabolism. Nature. (2016) 535:56-64. doi: 10.1038/nature18846

145. Eckburg PB, Bik EM, Bernstein CN, Purdom E, Dethlefsen L, Sargent M, et al. Diversity of the human intestinal microbial flora. Science. (2005) 308:1635-8. doi: 10.1126/science.1110591

146. Marchesi JR, Adams DH, Fava F, Hermes GDA, Hirschfield GM, Hold G, et al. The gut microbiota and host health: a new clinical frontier. Gut. (2016) 65:330-9. doi: 10.1136/gutjnl-2015-309990

147. Mentella MC, Scaldaferri F, Pizzoferrato M, Gasbarrini A, Miggiano GAD. Nutrition, IBD and gut microbiota: a review. Nutrients. (2020) 12:120. doi: 10.3390/nu12040944

148. Vrakas S, Mountzouris KC, Michalopoulos G, Karamanolis G, Papatheodoridis G, Tzathas C, et al. Intestinal bacteria composition and translocation of bacteria in inflammatory bowel disease. PLOS ONE. (2017) 12:e170034. doi: 10.1371/journal.pone.0170034

149. Seishima J, Iida N, Kitamura K, Yutani M, Wang ZY, Seki A, et al. Gut-derived Enterococcus faecium from ulcerative colitis patients promotes colitis in a genetically susceptible mouse host. Genome Biol. (2019) 20:118. doi: 10.1186/s13059-019-1879-9

150. Rehman A, Rausch P, Wang J, Skieceviciene J, Kiudelis G, Bhagalia K, et al. Geographical patterns of the standing and active human gut microbiome in health and IBD. Gut. (2016) 65:238-48. doi: 10.1136/gutjnl-2014-308341

151. Knights D, Silverberg MS, Weersma RK, Gevers D, Dijkstra G, Huang HL, et al. Complex host genetics influence the microbiome in inflammatory bowel disease. Genome Med. (2014) 6:11. doi: 10.1186/s13073-014-0107-1

152. Morgan XC, Kabakchiev B, Waldron L, Tyler AD, Tickle TL, Milgrom R, et al. Associations between host gene expression, the mucosal microbiome, and clinical outcome in the pelvic pouch of patients with inflammatory bowel disease. Genome Biol. (2015) 16:67. doi: 10.1186/s13059-015-0637-x

153. Llewellyn SR, Britton GJ, Contijoch EJ, Vennaro OH, Mortha A, Colombel JF, et al. Interactions between diet and the intestinal microbiota alter intestinal permeability and colitis severity in Mice. Gastroenterology. (2018) 154:103746. doi: 10.1053/j.gastro.2017.11.030

154. Wishart DS, Feunang YD, Marcu A, Guo AC, Liang K, Vazquez-Fresno R, et al. HMDB 4.0: the human metabolome database for 2018. Nucleic Acids Res. (2018) 46:D608-17. doi: 10.1093/nar/gkx1089
155. Chen L, Collij V, Jaeger M, van den Munckhof ICL, Vich Vila A, Kurilshikov A, et al. Gut microbial co-abundance networks show specificity in inflammatory bowel disease and obesity. Nat Commun. (2020) 11:112. doi: 10.1038/s41467-020-17840-y

156. Biasi F, Astegiano M, Maina M, Leonarduzzi G, Poli G. Polyphenol supplementation as a complementary medicinal approach to treating inflammatory bowel disease. Curr Med Chem. (2011) 18:4851-65. doi: 10.2174/092986711797535263

157. Morgan XC, Tickle TL, Sokol H, Gevers D, Devaney KL, Ward DV, et al. Dysfunction of the intestinal microbiome in inflammatory bowel disease and treatment. Genome Biol. (2012) 13:1-18. doi: 10.1186/gb-2012-13-9-r79

158. Limon JJ, Tang J, Li DL, Wolf AJ, Michelsen KS, Funari V, et al. Malassezia is associated with Crohn's disease and exacerbates colitis in mouse models. Cell Host and Microbe. (2019) 25:377-88. doi: 10.1016/j.chom.2019.01.007

159. Wlodarska M, Kostic AD, Xavier RJ. An integrative view of microbiomehost interactions in inflammatory bowel diseases. Cell Host Microbe. (2015) 17:577-91. doi: 10.1016/j.chom.2015.04.008

160. Ni J, Wu GD, Albenberg L, Tomov VT. Gut microbiota and IBD: causation or correlation? Nat Rev Gastroenterol Hepatol. (2017) 14:57384. doi: 10.1038/nrgastro.2017.88

161. Khan I, Ullah N, Zha LJ, Bai YR, Khan A, Zhao T, et al. Alteration of gut microbiota in inflammatory bowel disease (IBD): cause or consequence? IBD treatment targeting the gut microbiome. Pathogens. (2019) 8:128. doi: 10.3390/pathogens 8030126

162. Luo AN, Leach ST, Barres R, Hesson LB, Grimm MC, Simar D. The microbiota and epigenetic regulation of $\mathrm{T}$ helper $17 /$ regulatory $\mathrm{T}$ cells: in search of a balanced immune system. Front Immunol. (2017) 8:417. doi: 10.3389/fimmu.2017.00417

163. Grigg JB, Sonnenberg GF. Host-microbiota interactions shape local and systemic inflammatory diseases. J Immunol. (2017) 198:564-71. doi: 10.4049/jimmunol.1601621

164. Britton GJ, Contijoch EJ, Mogno I, Vennaro OH, Llewellyn SR, Ng R, et al. Microbiotas from humans with inflammatory bowel disease alter the balance of Gut Th17 and ROR gamma $\mathrm{T}(+)$ regulatory $\mathrm{T}$ cells and exacerbate colitis in mice. Immunity. (2019) 50:212-24. doi: 10.1016/j.immuni.2018. 12.015

165. Atarashi K, Tanoue T, Shima T, Imaoka A, Kuwahara T, Momose Y, et al. Induction of colonic regulatory $\mathrm{T}$ cells by indigenous Clostridium species. Science. (2011) 331:337-41. doi: 10.1126/science.1198469

166. Round JL, Lee SM, Li J, Tran G, Jabri B, Chatila TA, et al. The Toll-like receptor 2 pathway establishes colonization by a commensal of the human microbiota. Science. (2011) 332:974-7. doi: 10.1126/science.1206095

167. Quevrain E, Maubert MA, Michon C, Chain F, Marquant R, Tailhades J, et al. Identification of an anti-inflammatory protein from Faecalibacterium prausnitzii, a commensal bacterium deficient in Crohn's disease. Gut. (2016) 65:415-25. doi: 10.1136/gutjnl-2014-307649

168. Png CW, Linden SK, Gilshenan KS, Zoetendal EG, McSweeney CS, Sly LI, et al. Mucolytic bacteria with increased prevalence in IBD mucosa augment in vitro utilization of mucin by other bacteria. Amer J Gastroenterol. (2010) 105:2420-8. doi: 10.1038/ajg.2010.281

169. Lee YK, Mehrabian P, Boyajian S, Wu W-L, Selicha J, Vonderfecht $\mathrm{S}$, et al. The protective role of bacteroides fragilis in murine model of colitis-associated colorectal cancer. Msphere. (2018) 3:e0587-18. doi: 10.1128/mSphere.00587-18

170. Moura FA, de Andrade KQ, dos Santos JCF, Araujo ORP, Goulart MOF. Antioxidant therapy for treatment of inflammatory bowel disease: does it work? Redox Biol. (2015) 6:617-39. doi: 10.1016/j.redox.2015.10.006

171. Lane ER, Zisman TL, Suskind DL. The microbiota in inflammatory bowel disease: current and therapeutic insights. J Inflamm Res. (2017) 10:6373. doi: $10.2147 /$ jir.S116088

172. Johansson MEV, Larsson JMH, Hansson GC. The two mucus layers of colon are organized by the MUC2 mucin, whereas the outer layer is a legislator of host-microbial interactions. Proc Natl Acad Sci USA. (2011) 108:4659-65. doi: 10.1073/pnas.1006451107

173. Jandhyala SM, Talukdar R, Subramanyam C, Vuyyuru H, Sasikala M, Reddy DN. Role of the normal gut microbiota. World J Gastroenterol. (2015) 21:8787-803. doi: 10.3748/wjg.v21.i29.8787 
174. Kostic AD, Xavier RJ, Gevers D. The microbiome in inflammatory bowel disease: current status and the future ahead. Gastroenterology. (2014) 146:1489-99. doi: 10.1053/j.gastro.2014.02.009

175. Azuma T, Shigeshiro M, Kodama M, Tanabe S, Suzuki T. Supplemental naringenin prevents intestinal barrier defects and inflammation in colitic mice. J Nutr. (2013) 143:827-34. doi: 10.3945/jn.113.174508

176. Xiong YJ, Deng ZB, Liu JN, Qiu JJ, Guo L, Feng PP, et al. Enhancement of epithelial cell autophagy induced by sinensetin alleviates epithelial barrier dysfunction in colitis. Pharmacol Res. (2019) 148:10. doi: 10.1016/j.phrs.2019.104461

177. Bian Y, Dong Y, Sun J, Sun M, Hou Q, Lai Y, et al. Protective effect of kaempferol on lps-induced inflammation and barrier dysfunction in a coculture model of intestinal epithelial cells and intestinal microvascular endothelial cells. J Agric Food Chem. (2020) 68:160-7. doi: 10.1021/acs.jafc.9b06294

178. Chen S, Zhao H, Cheng N, Cao W. Rape bee pollen alleviates dextran sulfate sodium (DSS)-induced colitis by neutralizing IL-1 $\beta$ and regulating the gut microbiota in mice. Food Res Int. (2019) 122:24151. doi: 10.1016/j.foodres.2019.04.022

179. Park MY, Ji GE, Sung MK. Dietary kaempferol suppresses inflammation of dextran sulfate sodium-induced colitis in mice. Dig Dis Sci. (2012) 57:35563. doi: 10.1007/s10620-011-1883-8

180. Zhu L, Shen H, Gu PQ, Liu YJ, Zhang L, Cheng JF. Baicalin alleviates TNBSinduced colitis by inhibiting PI3K/AKT pathway activation. Exp Ther Med. (2020) 20:581-90. doi: 10.3892/etm.2020.8718

181. Xu J, Liu J, Yue G, Sun M, Li J, Xiu X, et al. Therapeutic effect of the natural compounds baicalein and baicalin on autoimmune diseases. Mol Med Rep. (2018) 18:1149-54. doi: 10.3892/mmr.2018.9054

182. Han YM, Koh J, Kim JH, Lee J, Im JP, Kim JS. Astragalin inhibits nuclear factor- $\kappa \mathrm{B}$ signaling in human colonic epithelial cells and attenuates experimental colitis in mice. Gut Liver. (2020) 15:100-8. doi: 10.5009/gnl19268

183. Peng L, Gao X, Nie L, Xie J, Dai T, Shi C, et al. Astragalin attenuates dextran sulfate sodium (DSS)-induced acute experimental colitis by alleviating gut microbiota dysbiosis and inhibiting NF- $\kappa \mathrm{B}$ activation in mice. Front Immunol. (2020) 11:2058. doi: 10.3389/fimmu.2020.02058

184. Lin R, Piao M, Song Y. Dietary quercetin increases colonic microbial diversity and attenuates colitis severity in Citrobacter rodentium-infected mice. Front Microbiol. (2019) 10:1092. doi: 10.3389/fmicb.2019.01092

185. Ju S, Ge Y, Li P, Tian X, Wang H, Zheng X, et al. Dietary quercetin ameliorates experimental colitis in mouse by remodeling the function of colonic macrophages via a heme oxygenase-1-dependent pathway. Cell Cycle. (2018) 17:53-63. doi: 10.1080/15384101.2017.1387701

186. Yu J, Guo H, Xie J, Luo J, Li Y, Liu L, et al. The alternate consumption of quercetin and alliin in the traditional asian diet reshaped microbiota and altered gene expression of colonic epithelial cells in rats. J Food Sci. (2019) 84:678-86. doi: 10.1111/1750-3841.14473

187. Oteiza PI, Fraga CG, Mills DA, Taft DH. Flavonoids and the gastrointestinal tract: local and systemic effects. Mol Aspects Med. (2018) 61:419. doi: 10.1016/j.mam.2018.01.001

188. Martini E, Krug SM, Siegmund B, Neurath MF, Becker C. Mend your fences the epithelial barrier and its relationship with mucosal immunity in inflammatory bowel disease. Cell Mol Gastroenterol Hepatol. (2017) 4:3346. doi: 10.1016/j.jcmgh.2017.03.007

189. Chang J, Leong RW, Wasinger VC, Ip M, Yang M, Phan TG. Impaired intestinal permeability contributes to ongoing bowel symptoms in patients with inflammatory bowel disease and mucosal healing. Gastroenterology. (2017) 153:723-31. doi: 10.1053/j.gastro.2017.05.056

190. Iwaya H, Maeta K, Hara H, Ishizuka S. Mucosal permeability is an intrinsic factor in susceptibility to dextran sulfate sodium-induced colitis in rats. Exp Biol Med. (2012) 237:451-60. doi: 10.1258/ebm.2011. 011269

191. Nighot P, Al-Sadi R, Rawat M, Guo SH, Watterson DM, Ma T. Matrix metalloproteinase 9-induced increase in intestinal epithelial tight junction permeability contributes to the severity of experimental DSS colitis. Amer Jo Physiol Gastrointest Liver Physiol. (2015) 309:G98897. doi: 10.1152/ajpgi.00256.2015
192. Li SY, Wu BN, Fu WY, Reddivari L. The anti-inflammatory effects of dietary anthocyanins against ulcerative colitis. Int J Mol Sci. (2019) 20:18. doi: 10.3390/ijms20102588

193. Suzuki T, Hara H. Quercetin enhances intestinal barrier function through the assembly of zonnula occludens-2, occludin, and claudin-1 and the expression of claudin-4 in Caco-2 cells. J Nutr. (2009) 139:96574. doi: 10.3945/jn.108.100867

194. Suzuki T, Tanabe S, Hara H. Kaempferol enhances intestinal barrier function through the cytoskeletal association and expression of tight junction proteins in Caco-2 cells. J Nutr. (2011) 141:87-94. doi: 10.3945/jn.110.125633

195. Cibor D, Domagala-Rodacka R, Rodacki T, Jurczyszyn A, Mach T, Owczarek D. Endothelial dysfunction in inflammatory bowel diseases: pathogenesis, assessment and implications. World J Gastroenterol. (2016) 22:106777. doi: 10.3748/wjg.v22.i3.1067

196. Bian Y, Liu P, Zhong J, Hu Y, Fan Y, Zhuang S, et al. Kaempferol inhibits multiple pathways involved in the secretion of inflammatory mediators from LPS-induced rat intestinal microvascular endothelial cells. Mol Med Rep. (2019) 19:1958-64. doi: 10.3892/mmr.2018.9777

197. Liu P, Bian YF, Fan YS, Zhong J, Liu ZJ. Protective effect of naringin on in vitro gut-vascular barrier disruption of intestinal microvascular endothelial cells induced by TNF- $\alpha$. J Agric Food Chem. (2020) 68:16875. doi: 10.1021/acs.jafc.9b06347

198. Maleki SJ, Crespo JF, Cabanillas B. Anti-inflammatory effects of flavonoids. Food Chem. (2019) 299:11. doi: 10.1016/j.foodchem.2019.125124

199. Wallace KL, Zheng LB, Kanazawa Y, Shih DQ. Immunopathology of inflammatory bowel disease. World J Gastroenterol. (2014) 20:621. doi: 10.3748/wjg.v20.i1.6

200. Tao FF, Qian C, Guo WJ, Luo Q, Xu Q, Sun Y. Inhibition of Th1/Th17 responses via suppression of STAT1 and STAT3 activation contributes to the amelioration of murine experimental colitis by a natural flavonoid glucoside icariin. Biochem Pharmacol. (2013) 85:798807. doi: 10.1016/j.bcp.2012.12.002

201. Abron JD, Singh NP, Price RL, Nagarkatti M, Nagarkatti PS, Singh UP. Genistein induces macrophage polarization and systemic cytokine to ameliorate experimental colitis. PLOS ONE. (2018) 13:e0199631. doi: 10.1371/journal.pone.0199631

202. Yoshida T. Concise commentary: quercetin flavonoid of the month or IBD therapy? Dig Dis Sci. (2018) 63:3305-6. doi: 10.1007/s10620-018-5269-z

203. Cui L, Feng L, Zhang ZH, Jia XB. The anti-inflammation effect of baicalin on experimental colitis through inhibiting TLR4/NF- $\kappa \mathrm{B}$ pathway activation. Int Immunopharmacol. (2014) 23:294-303. doi: 10.1016/j.intimp.2014.09.005

204. Eun SH, Woo JT, Kim DH. Tangeretin inhibits IL-12 expression and NF-кB activation in dendritic cells and attenuates colitis in mice. Planta Med. (2017) 83:527-33. doi: 10.1055/s-0042-119074

205. Manigandan K, Manimaran D, Jayaraj RL, Elangovan N, Dhivya V, Kaphle A. Taxifolin curbs NF-кB-mediated Wnt/ $\beta$-catenin signaling via up-regulating Nrf2 pathway in experimental colon carcinogenesis. Biochimie. (2015) 119:103-12. doi: 10.1016/j.biochi.2015.10.014

206. Willing BP, Dicksved J, Halfvarson J, Andersson AF, Lucio M, Zheng Z, et al. A pyrosequencing study in twins shows that gastrointestinal microbial profiles vary with inflammatory bowel disease phenotypes. Gastroenterology. (2010) 139:1844.e1-54.e1. doi: 10.1053/j.gastro.2010.08.049

207. Hong Z, Piao M. Effect of quercetin monoglycosides on oxidative stress and gut microbiota diversity in mice with dextran sodium sulphate-induced colitis. Biomed Res Int. (2018) 2018:8343052. doi: 10.1155/2018/8343052

208. Bian XY, Wu WR, Yang LY, Lv LX, Wang Q, Li YT, et al. Administration of Akkermansia muciniphila ameliorates dextran sulfate sodium-induced ulcerative colitis in mice. Front Microbiol. (2019) 10:2259. doi: 10.3389/fmicb.2019.02259

209. Everard A, Belzer C, Geurts L, Ouwerkerk JP, Druart C, Bindels LB, et al. Cross-talk between Akkermansia muciniphila and intestinal epithelium controls diet-induced obesity. Proc Natl Acad Sci USA. (2013) 110:906671. doi: $10.1073 /$ pnas. 1219451110

210. Roopchand DE, Carmody RN, Kuhn P, Moskal K, Rojas-Silva P, Turnbaugh PJ, et al. Dietary polyphenols promote growth of the gut bacterium Akkermansia muciniphila and attenuate high-fat diet-induced metabolic syndrome. Diabetes. (2015) 64:2847-58. doi: 10.2337/db14-1916 
211. Zhang L, Carmody RN, Kalariya HM, Duran RM, Moskal K, Poulev A, et al. Grape proanthocyanidin-induced intestinal bloom of Akkermansia muciniphila is dependent on its baseline abundance and precedes activation of host genes related to metabolic health. J Nutr Biochem. (2018) 56:14251. doi: 10.1016/j.jnutbio.2018.02.009

212. Ananthakrishnan AN. Clostridium difficile infection: epidemiology, risk factors and management. Nat Rev Gastroenterol Hepatol. (2011) 8:1726. doi: 10.1038/nrgastro.2010.190

213. Hudson LE, Anderson SE, Corbett AH, Lamb TJ. Gleaning insights from fecal microbiota transplantation and probiotic studies for the rational design of combination microbial therapies. Clin Microbiol Rev. (2017) 30:191231. doi: $10.1128 / \mathrm{cmr} .00049-16$

214. Wu X, Alam MZ, Feng L, Tsutsumi LS, Sun D, Hurdle JG. Prospects for flavonoid and related phytochemicals as nature-inspired treatments for Clostridium difficile infection. J Appl Microbiol. (2014) 116:2331. doi: 10.1111/jam.12344

215. Pellissery AJ, Vinayamohan PG, Venkitanarayanan K. In vitro antivirulence activity of baicalin against Clostridioides difficile. J Med Microbiol. (2020) 69:631-9. doi: 10.1099/jmm.0.001179

216. González-Quilen C, Rodríguez-Gallego E, Beltrán-Debón R, Pinent M, Ardévol A, Blay MT, et al. Health-promoting properties of proanthocyanidins for intestinal dysfunction. Nutrients. (2020) 12:130. doi: 10.3390/nu12010130

217. Salaritabar A, Darvishi B, Hadjiakhoondi F, Manayi A, Sureda A, Nabavi SF, et al. Therapeutic potential of flavonoids in inflammatory bowel disease: a comprehensive review. World J Gastroenterol. (2017) 23:5097114. doi: 10.3748/wjg.v23.i28.5097

218. Brueckner M, Westphal S, Domschke W, Kucharzik T, Luegering A. Green tea polyphenol epigallocatechin-3-gallate shows therapeutic antioxidative effects in a murine model of colitis. J Crohns Colitis. (2012) 6:22635. doi: 10.1016/j.crohns.2011.08.012

219. Al-Rejaie SS, Abuohashish HM, Al-Enazi MM, Al-Assaf AH, Parmar MY, Ahmed MM. Protective effect of naringenin on acetic acidinduced ulcerative colitis in rats. World J Gastroenterol. (2013) 19:563344. doi: 10.3748/wjg.v19.i34.5633

220. Ananthakrishnan AN, Bernstein CN, Iliopoulos D, Macpherson A, Neurath MF, Ali RAR, et al. Environmental triggers in IBD: a review of progress and evidence. Nat Rev Gastroenterol Hepatol. (2018) 15:3949. doi: 10.1038/nrgastro.2017.136

221. Ribeiro D, Proenca C, Rocha S, Lima J, Carvalho F, Fernandes E, et al. Immunomodulatory effects of flavonoids in the prophylaxis and treatment of inflammatory bowel diseases: a comprehensive review. Curr Med Chem. (2018) 25:3374-412. doi: 10.2174/ 0929867325666180214121734

222. Etxeberria U, Fernandez-Quintela A, Milagro FI, Aguirre L, Alfredo Martinez J, Portillo MP. Impact of polyphenols and polyphenol-rich dietary sources on gut microbiota composition. J Agric Food Chem. (2013) 61:951733. doi: $10.1021 /$ jf $402506 \mathrm{c}$

223. Gee JM, DuPont MS, Day AJ, Plumb GW, Williamson G, Johnson IT. Intestinal transport of quercetin glycosides in rats involves both deglycosylation and interaction with the hexose transport pathway. J Nutr. (2000) 130:2765-71. doi: 10.1093/jn/130.11.2765

224. Day AJ, Canada FJ, Diaz JC, Kroon PA, McLauchlan R, Faulds CB, et al. Dietary flavonoid and isoflavone glycosides are hydrolysed by the lactase site of lactase phlorizin hydrolase. FEBS Lett. (2000) 468:16670. doi: 10.1016/s0014-5793(00)01211-4

225. Williamson G, Kay CD, Crozier A. The bioavailability, transport, and bioactivity of dietary flavonoids: a review from a historical perspective. Compr Rev Food Sci Food Saf. (2018) 17:1054112. doi: 10.1111/1541-4337.12351

226. Williamson G, Clifford MN. Role of the small intestine, colon and microbiota in determining the metabolic fate of polyphenols. Biochem Pharmacol. (2017) 139:24-39. doi: 10.1016/j.bcp.2017.03.012

Conflict of Interest: The authors declare that the research was conducted in the absence of any commercial or financial relationships that could be construed as a potential conflict of interest.

Publisher's Note: All claims expressed in this article are solely those of the authors and do not necessarily represent those of their affiliated organizations, or those of the publisher, the editors and the reviewers. Any product that may be evaluated in this article, or claim that may be made by its manufacturer, is not guaranteed or endorsed by the publisher.

Copyright (c) 2021 Wang, Gao, Kang and Huang. This is an open-access article distributed under the terms of the Creative Commons Attribution License (CC BY). The use, distribution or reproduction in other forums is permitted, provided the original author(s) and the copyright owner(s) are credited and that the original publication in this journal is cited, in accordance with accepted academic practice. No use, distribution or reproduction is permitted which does not comply with these terms. 